\title{
Hydrides as High Capacity Anodes in Lithium Cells: An Italian "Futuro in Ricerca di Base FIRB-2010" Project
}

\author{
Sergio Brutti ${ }^{1,2, *}$, Stefania Panero ${ }^{3}$, Annalisa Paolone ${ }^{2}$, Sara Gatto ${ }^{2}$, Daniele Meggiolaro ${ }^{2,3}$, \\ Francesco M. Vitucci ${ }^{2}$, Jessica Manzi ${ }^{1,2}$, David Munaò ${ }^{3}$, Laura Silvestri ${ }^{3}$, Luca Farina ${ }^{3}$ and \\ Priscilla Reale ${ }^{4, *}$ \\ 1 Dipartimento di Scienze, Università della Basilicata, Potenza 85100, Italy; jessica.manzi@unibas.it \\ 2 ISC-CNR (Instituto dei Sistemi Complessi-Consiglio Nazionale delle Ricerche), Roma 00185, Italy; \\ annalisa.paolone@roma1.infn.it (A.P.); sarapingu@inwind.it (S.G.); \\ mjjldany@gmail.com (D.M.); francesco.vitucci@roma1.infn.it (F.M.V.) \\ 3 Dipartimento di Chimica, Università di Roma La Sapienza, Rome 24098, Italy; \\ stefania.panero@uniroma1.it (S.P.); david.munao@uniroma1.it (D.M.); \\ 1.silvestri@uniroma1.it (L.S.); luca.farina@uniroma1.it (L.F.) \\ 4 ENEA Centro Ricerche Frascati, Frascati 00044, Italy \\ * Correspondence: sergio.brutti@unibas.it (S.B.); priscilla.reale@enea.it (P.R.); \\ Tel.: +39-097-120-5455 (S.B.); +39-069-400-5847 (P.R.)
}

Academic Editor: Palmiro Poltronieri

Received: 30 January 2017; Accepted: 10 March 2017; Published: 16 March 2017

\begin{abstract}
Automotive and stationary energy storage are among the most recently-proposed and still unfulfilled applications for lithium ion devices. Higher energy, power and superior safety standards, well beyond the present state of the art, are actually required to extend the Li-ion battery market to these challenging fields, but such a goal can only be achieved by the development of new materials with improved performances. Focusing on the negative electrode materials, alloying and conversion chemistries have been widely explored in the last decade to circumvent the main weakness of the intercalation processes: the limitation in capacity to one or at most two lithium atoms per host formula unit. Among all of the many proposed conversion chemistries, hydrides have been proposed and investigated since 2008. In lithium cells, these materials undergo a conversion reaction that gives metallic nanoparticles surrounded by an amorphous matrix of $\mathrm{LiH}$. Among all of the reported conversion materials, hydrides have outstanding theoretical properties and have been only marginally explored, thus making this class of materials an interesting playground for both fundamental and applied research. In this review, we illustrate the most relevant results achieved in the frame of the Italian National Research Project FIRB 2010 Futuro in Ricerca "Hydrides as high capacity anodes in lithium cells" and possible future perspectives of research for this class of materials in electrochemical energy storage devices.
\end{abstract}

Keywords: hydrides; lithium; batteries

\section{Introduction}

Automotive and stationary energy storage are among the most recently-proposed and still unfulfilled applications for lithium ion devices. Higher energy, power and superior safety standards, well beyond the present state of the art, are actually required to extend the Li-ion battery market to these challenging fields, but such a goal can only be achieved by the development of new materials with improved performances [1-6]. 
Current lithium-ion batteries (LCO-C) are composed of a positive electrode, typically $\mathrm{LiCoO}_{2}$, a negative electrode, typically graphite and a non-aqueous organic liquid electrolyte. Possible alternative materials have been intensively studied over the past $15-20$ years [7]. The typical LCO-C cell is capable of supplying about $340-350 \mathrm{Wh} \cdot \mathrm{kg}^{-1}$ and a specific capacity $90-100 \mathrm{mAh} \cdot \mathrm{g}^{-1}$ (cell voltage $3.6 \mathrm{~V}$ ) with respect to the to the total weight of the cathode and anode active materials [1], or $100-120 \mathrm{Wh} \cdot \mathrm{kg}_{\text {tot }}{ }^{-1}$ with respect to the total weight of the battery (including current collectors, separators, electrolyte and the battery pack components). Therefore, Li-ion technology needs dramatic improvements to reach the short- $\left(150 \mathrm{Wh} \cdot \mathrm{kg}_{\text {tot }}{ }^{-1}\right)$ and long-term $\left(200 \mathrm{Wh} \cdot \mathrm{kg}_{\text {tot }}{ }^{-1}\right)$ advanced battery goals established by USABC (United States Advanced Battery Consortium) [8] to power an electrically-driven vehicle.

Great R\&D effort is currently spent worldwide to improve or replace the three components of the LCO-C battery by venturing into the introduction of revolutionary concepts. The latter innovations fall in the field of the so-called new-chemistries and should successfully tackle the most crucial limiting aspects of the Li-ion technology: performance, material toxicity, cost, natural abundance of the constituent elements and safety, this last mainly related to the use of carbonaceous anodes and carbonate-based electrolytes.

Lithium is inserted into graphite (intercalation process) at potentials below $1 \mathrm{~V} \mathrm{vs.} \mathrm{Li}^{+} / \mathrm{Li}$. At such low potentials, reduction of the electrolyte occurs, accompanied by the formation of a passivation film on the graphite surface. This effect leads to sacrificial charge consumption and dangerous gas evolution in the first insertion process. Moreover, most lithium is intercalated into graphite at potentials below $100 \mathrm{mV}$ vs. $\mathrm{Li}^{+} / \mathrm{Li}$ : again, at such very low potentials, Li could deposit on the anode surface, leading to catastrophic dendrite growth and internal short circuiting of the cell. These intrinsic drawbacks limit the improvements of carbonaceous material as anodes for Li-ion cells.

To circumvent the limitation of graphite-based anodes, new alternative materials have been proposed and systematically investigated in the last decade: low-voltage oxides (e.g., $\mathrm{Li}_{4} \mathrm{Ti}_{5} \mathrm{O}_{12}$ ) or metal alloys [9]. In both cases "going nano" has been shown to play a critical role. The reduced dimensions of the active materials promote successful lithium diffusion, increase electron transport, enlarge electrolyte wetting surfaces and modify lithium insertion thermodynamics due to the relevant surface effects on chemical potentials. These advantages are only partially balanced by a few disadvantages: the most difficult and expensive synthetic routes; amplification of side reactions on electrode surfaces; a decrease of volumetric performances due to the lower density of nanophases.

However, even the use of the most advanced nanomaterials cannot avoid the main weakness of the chemical processes based on intercalation/de-intercalation in negative electrodes: the limitation in capacity to one or at most two lithium atoms per host formula unit; hence the already mentioned interest in metal alloying, especially for Sn-based alloys and silicon [9].

However, despite their extraordinary theoretical capacities $\left(993 \mathrm{mAh} \cdot \mathrm{g}^{-1}, 1000 \mathrm{mAh} \cdot \mathrm{cc}^{-1}\right.$ and $4200 \mathrm{mAh} \cdot \mathrm{g}^{-1}$ and $1750 \mathrm{mAh} \cdot \mathrm{cc}^{-1}$ for $\mathrm{Sn}$ and $\mathrm{Si}$, respectively), alloying reactions suffer a large volume expansion/contraction upon accommodation of $4.4 \mathrm{Li}$ atoms per host atom. These volume changes, exceeding $450 \%$ for both $\mathrm{Sn}$ and $\mathrm{Si}$, lead to a rapid deterioration of the electrode, thus limiting its lifetime. Several solutions have been studied, mainly by paying attention to electrode engineering. Good results have been obtained with metal-carbon composites, but at the expense of specific capacity [10].

Besides alloying, an alternative class of chemical processes has been proven to overcome the capacity limitation of intercalation: conversion reactions [11].

In a conversion reaction, the active phase $\mathrm{M}_{x} \mathrm{~A}_{\mathrm{y}}$, is electrochemically reduced to a composite material consisting of nanometric metallic particles dispersed in an amorphous LimA matrix according to the equation: $\mathrm{M}_{\mathrm{x}} \mathrm{A}_{\mathrm{y}}+\mathrm{ne}^{-}+\mathrm{nLi}^{+}=\mathrm{xM}^{0}+\mathrm{yLi} \mathrm{m} \mathrm{A}$, where $\mathrm{e}^{-}$and $\mathrm{Li}^{+}$are the electron and the lithium ion, respectively, and $\mathrm{m}=\mathrm{n} / \mathrm{y}$. This concept has been widely accepted as promising for a number of different materials, such as oxides, nitrides, phosphides, sulfides as negative electrodes and fluorides for the positive electrodes. Moreover, depending on the oxidation state of the metal, these reactions 
have been reported to involve one $\left(\mathrm{Cu}_{2} \mathrm{O}\right)$, two $(\mathrm{MnO})$, three $\left(\mathrm{Fe}_{2} \mathrm{O}_{3}\right)$ or four $\left(\mathrm{RuO}_{2}\right)$ electrons. As a consequence, innovative negative electrodes can be developed with outstanding capacity improvements over graphite or insertion oxides, while using low-cost and environmentally-friendly elements, such as manganese and iron.

The major drawback of this class of reactions is the poor kinetics and the consequent large voltage difference between the Li uptake and removal processes, leading to poor energy efficiency. The magnitude of this negative effect is apparently determined by the nature of the negative counter-ion " $\mathrm{A}$ " of the active species. This evidence suggests that the transport of the mobile ions is a key factor [12].

\section{The Futuro in Ricerca di Base FIRB-2010 Futuro in Ricerca Project}

\subsection{Basic Ideas}

Within the large family of conversion reactions, in 2008, Tarascon and co-workers suggested and experimentally demonstrated the use of metallic hydrides and the exploitation of the H-shifting reaction $\mathrm{M}_{\mathrm{x}} \mathrm{M}_{\mathrm{y}}^{\prime} \mathrm{H}_{\mathrm{z}}+\mathrm{zLi}^{+}+\mathrm{ze}^{-}=\mathrm{M}_{\mathrm{x}} \mathrm{M}_{\mathrm{y}}^{\prime}+\mathrm{zLiH}$ (hydride conversion reactions (HCR)) $[13,14]$. In particular, reversible conversion reactions for $\mathrm{TiH}_{2}$ and $\mathrm{MgH}_{2}$ have been proven in standard $\mathrm{LiPF}_{6}$ dimethyl carbonate-ethylene carbonate electrolyte cells versus metallic lithium. Furthermore, in the case of $\mathrm{MgH}_{2}$, extended cycling (50 cycles) with capacities approaching $500 \mathrm{mAh} \cdot \mathrm{g}^{-1}$, with respect to the anode active material weight, has been proven. Besides these two hydrides, the occurrence of hydride conversion reactions in the $\mathrm{NaH}, \mathrm{Mg}_{2} \mathrm{NiH}_{4}$ and $\mathrm{LaNi}_{4.25} \mathrm{Mn}_{0.75} \mathrm{H}_{5}$ systems has also been demonstrated. This outstanding breakthrough has highlighted metal hydrides among all conversion reaction materials for two main reasons: (1) these systems are able to provide high theoretical specific capacities $\left(2037 \mathrm{mAh} \cdot \mathrm{g}^{-1}\right.$ for $\left.\mathrm{MgH}_{2}\right)$ in a safer potential window $\left(0.1-0.5 \mathrm{~V} \mathrm{vs} . \mathrm{Li}^{+} / \mathrm{Li}\right)$ compared to carbons with respect to the possible occurrence of Li-plating; and (2) these reactions show the lowest ever reported voltage difference between charge and discharge for a conversion process $(0.25 \mathrm{~V}$ for $\mathrm{MgH}_{2}$ to be compared to 1.1, 0.9, 0.7, 0.6 and $0.4 \mathrm{~V}$ for fluorides, oxides, sulfides, nitrides and phosphides). Although very limited, these findings were extraordinary and naturally asked to venture into the investigation on the hydrides class of materials for Li-ion battery application. This research field required tackling fundamental issues that were completely unexplored.

Up to 2012, besides the results reported by Tarascon, Aymard and co-workers [13-16], in the literature, there were no other experimental or theoretical papers and general reviews about this new class of conversion reactions; also quantitative evaluations about the potential of these processes were missing. The wide hydride field (thousands of hydrides are known) was completely open to research at the beginning of the project.

In 2012, on the basis of hypothetical conversion reactions involving the most popular hydride materials, we proposed some very encouraging preliminary predictions [17].

A representation of the theoretical capacities of a selection of hydrides is presented in Figure 1a (for all hydrides, the HCR is postulated from the experimental $\mathrm{H}_{2}$ desorptions by assuming that the de- $\mathrm{H}$ states are identical in both cases; e.g., $\mathrm{H}_{2}$, desorption: $\mathrm{M}_{\mathrm{x}} \mathrm{M}_{\mathrm{y}}^{\prime} \mathrm{H}_{\mathrm{z}}=\mathrm{M}_{\mathrm{x}} \mathrm{M}_{\mathrm{y}}^{\prime}+\mathrm{z} / 2 \mathrm{H}_{2} \rightarrow \mathrm{HCR}$ : $\left.\mathrm{M}_{\mathrm{x}} \mathrm{M}_{\mathrm{y}}^{\prime} \mathrm{H}_{\mathrm{z}}+\mathrm{zLi}^{+}+\mathrm{ze}^{-}=\mathrm{M}_{\mathrm{x}} \mathrm{M}_{\mathrm{y}}^{\prime}+\mathrm{zLiH}\right)$. The corresponding estimated volume expansion upon conversion is shown in Figure 1b.

Although those reported in Figure 1 are only estimates, the potential of the hydride conversion reactions is literally self-explanatory. Furthermore, similar predictions for volume changes upon lithiation (Figure $1 \mathrm{~b}$ ) suggest volume expansions smaller than $200 \%$ and thermodynamic potentials in the range $0.1-0.8 \mathrm{~V}$ for all of the hydrides shown in Figure 1a. For the sake of completeness, it is important to underline that the $0.1-0.8 \mathrm{~V}$ vs. $\mathrm{Li}+/ \mathrm{Li}$ operating potential window is outside the stability window of the most typical commercial liquid electrolytes for Li-ion batteries. Therefore, the stability of the electrode/electrolyte interface may be a critical issue for these classes of candidate negative electrode materials. 


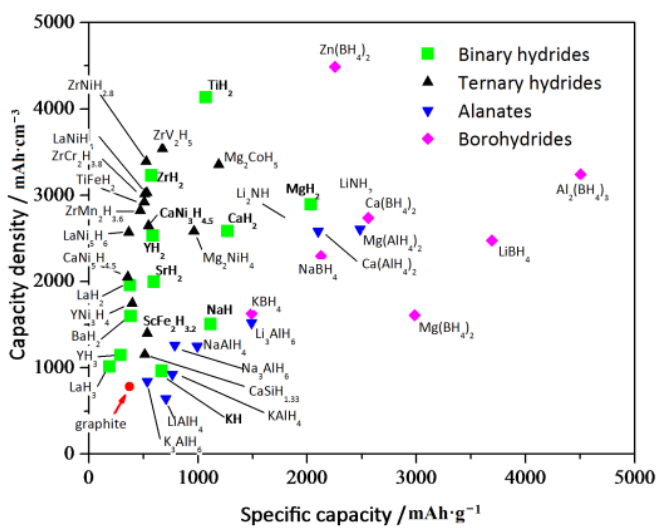

(a)

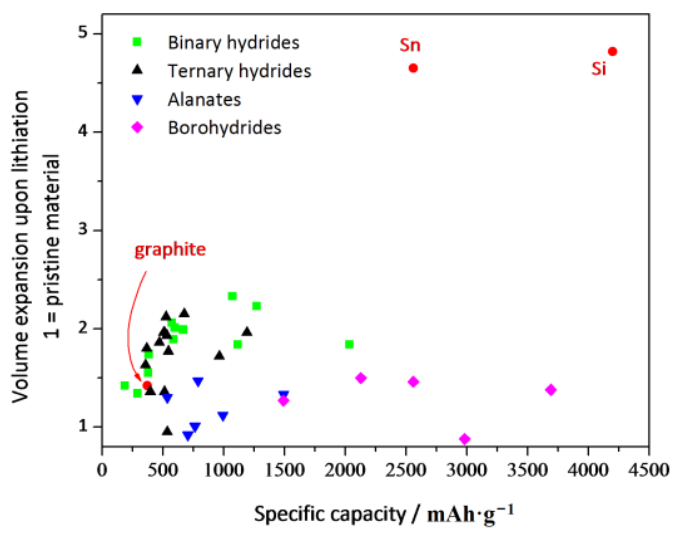

(b)

Figure 1. (a) Gravimetric and volumetric theoretical specific capacity estimated for a selected number of hydrides; (b) volume expansion upon conversion estimated for the same hydride families.

This project had the ambition to explore and develop the potentialities of hydrides as new conversion anodes for lithium ion batteries and to finally achieve a lab-scale prototype of a complete Li-ion cell with a hydride-conversion reaction (HCR) anode, a cathode material and a liquid electrolyte, providing a meaningful performances advancement with respect to the lithium ion technology state of the art. Before illustrating the general approach adopted in this project and the most relevant results achieved, it is important to recall the main challenges of these materials:

1. The lack of experimental evidence of the electrochemical activity and HCR reversibility of almost all metallic and complex hydrides in lithium cells;

2. The weak demonstration of an extended cycling ability of these materials in lithium cells;

3. The almost negligible analysis of the chemical and electrochemical stability of the electrolyte/electrode interface in lithium cells.

\subsection{Hydride Selection}

In general, hydrogen storage materials include an enormous number of different chemical species that can be usefully grouped into two categories: hydrides and high surface area materials for $\mathrm{H}_{2}$ physisorption. In hydrides, the bonded hydrogen resides mainly in the bulk of the material, and this category includes hydriding alloys, molecular hydride complexes and other molecular covalent compounds, such as amine complexes and hydrocarbons [18]. As a further classification, hydrides can be grouped into three main types, according to the nature of their bonding: ionic hydrides; covalent hydrides; interstitial/metallic hydrides [18,19].

The number of hydrogen storage materials listed in the Hydride Material Listing Database (database published and updated on the web by the Sandia National Laboratories under the umbrella of a specific project funded by the Department of Energy (DOE) USA [20]) reports more than 2722 entries grouped into eight sub-categories: intermetallic phases with $\mathrm{AB}_{5}, \mathrm{AB}_{2}, \mathrm{AB}$ and $\mathrm{A}_{2} \mathrm{~B}$ stoichiometries, complex compounds, Mg-alloys, miscellaneous other intermetallic compounds and solid solution alloys [20]. In order to select an affordable number of hydrides to be investigated, three main criteria have been identified:

1. Cost and environmental compatibility: Candidate hydrides are required to be constituted by atomic elements that are naturally abundant and thus not expensive. They must be environmentally friendly, non-toxic non-explosive, non-pyrophoric and possibly inert to water and oxygen. Among the light elements, the latter constraint necessarily implies discarding Be-based hydrides and to strongly limit $\mathrm{V}$ and $\mathrm{Co}$. 
2. Estimated theoretical performances: Candidate hydrides must show theoretical capacities as high as possible, at least higher than that of graphite $\left(370 \mathrm{mAh} \cdot \mathrm{g}^{-1}\right.$ or $\left.550 \mathrm{mAh} \cdot \mathrm{cc}^{-1}\right)$. Furthermore, in order to assure both the safety and high energy in the final application, the estimated Nernst working potential in the corresponding HCR must range between 1 and $0.1 \mathrm{~V} \mathrm{vs.} \mathrm{Li}$, far from the Li deposition potential.

3. Safety constraint: Selected hydrides must be stable from room temperature up to $200-250{ }^{\circ} \mathrm{C}$ with a negligible $\mathrm{H}_{2}$ desorption pressure at room temperature; quantitatively, this parameter is given by the so-called hydride decomposition temperature, which accordingly, is required to be $>200{ }^{\circ} \mathrm{C}$.

Furthermore, besides these criteria, a "chemical-common-sense" evaluation suggested that de-alloying/de-mixing of the $\mathrm{M}_{\mathrm{x}} \mathrm{M}_{\mathrm{y}}^{\prime}$ de-hydrogenated (de-H) phase is expected to be a source of irreversibilities and should preferably be avoided. In view of this, the ternary or multinary hydrides that have a non-stable de- $\mathrm{H}$ state must be critically checked. These criteria are all to be taken into account to meet the requirements for a successful development of a material able to cycle reversibly and safely in a conversion reaction. However, the negligible consolidated background in the field suggested that minor exceptions for materials with outstanding theoretical performances could be accepted.

Eight hydrides match all three criteria $\left(\mathrm{MgH}_{2}, \mathrm{TiH}_{2}, \mathrm{NaH}, \mathrm{CaH}_{2}, \mathrm{Mg}_{2} \mathrm{NiH}_{4}, \mathrm{LiBH}_{4}, \mathrm{Mg}\left(\mathrm{BH}_{4}\right)_{2}\right.$, $\mathrm{LiNH}_{2}$ ), but a further nine candidates have been identified by critically excepting the unmatched criteria; these are: $\mathrm{Mg}_{2} \mathrm{FeH}_{6}, \mathrm{LiAlH}_{4}, \mathrm{Li}_{3} \mathrm{AlH}_{6}, \mathrm{NaAlH}_{4}, \mathrm{Na}_{3} \mathrm{AlH}_{6}$ and $\mathrm{LiNa}_{2} \mathrm{AlH}_{6}, \mathrm{NaBH}_{4}, \mathrm{KBH}_{4}$ and $\mathrm{Ca}\left(\mathrm{BH}_{4}\right)_{2}$, which are expected to give complex de-H states (indeed, $\mathrm{LiAlH}_{4}$ thermal stability is poor, but it was interesting to compare with the other alanates).

The selected 17 hydrides were grouped as follows: (i) simple metal hydrides, i.e., $\mathrm{MgH}_{2}, \mathrm{TiH}_{2}$, $\mathrm{NaH}, \mathrm{CaH}_{2}$; (ii) borohydrides, i.e., $\mathrm{LiBH}_{4}, \mathrm{NaBH}_{4}, \mathrm{KBH}_{4}, \mathrm{Ca}\left(\mathrm{BH}_{4}\right)_{2}$ and $\mathrm{Mg}\left(\mathrm{BH}_{4}\right)_{2}$; (iii) alanates, i.e., $\mathrm{LiAlH}_{4}, \mathrm{Li}_{3} \mathrm{AlH}_{6}, \mathrm{NaAlH}_{4}, \mathrm{Na}_{3} \mathrm{AlH}_{6}$ and $\mathrm{LiNa}_{2} \mathrm{AlH}_{6}$; (iv) other complex hydrides, i.e., $\mathrm{Mg}_{2} \mathrm{NiH}_{4}$ and $\mathrm{Mg}_{2} \mathrm{FeH}_{6}$. The crystal symmetry, formula weight and estimated theoretical capacity of the hydrides selected are summarized in Table 1.

Table 1. Crystal symmetry, formula weight and theoretical capacity of the simple hydrides.

\begin{tabular}{cccc}
\hline Hydride & Symmetry Space Group & $\begin{array}{c}\text { Formula Weight } \\
\left(\mathbf{g} \cdot \mathbf{m o l}^{-\mathbf{1}} \mathbf{)}\right.\end{array}$ & $\begin{array}{c}\text { Theoretical Capacity } \\
\left(\mathbf{m A h} \cdot \mathbf{g}^{-\mathbf{1}}\right)\end{array}$ \\
\hline $\mathrm{MgH}_{2}$ & $\mathrm{Pbcn}$ & 26.3 & 2037 \\
$\mathrm{NaH}$ & $\mathrm{Fm}-3 \mathrm{~m}$ & 24.0 & 1117 \\
$\mathrm{TiH}_{2}$ & $\mathrm{I} / \mathrm{mmm}$ & 49.9 & 1075 \\
$\mathrm{CaH}_{2}$ & $\mathrm{Pnma}$ & 42.1 & 1273 \\
$\mathrm{LiBH}_{4}$ & $\mathrm{Pnma}$ & 21.8 & 4992 \\
$\mathrm{NaBH}_{4}$ & $\mathrm{P}-42_{1} \mathrm{C}$ & 37.8 & 2834 \\
$\mathrm{KBH}_{4}$ & $\mathrm{P} 42_{1} \mathrm{c}$ & 53.9 & 1987 \\
$\mathrm{Mg}\left(\mathrm{BH}_{4}\right)_{2}$ & $\mathrm{P} 6_{1} 22$ & 54.0 & 3971 \\
$\mathrm{Ca}\left(\mathrm{BH}_{4}\right)_{2}$ & $\alpha \mathrm{Fddd}$ & 69.8 & 3074 \\
$\mathrm{LiAlH}_{4}$ & $\beta \mathrm{P} 4_{2} / \mathrm{m}$ & 37.9 & 2119 \\
$\mathrm{Li}_{3} \mathrm{AlH}_{6}$ & $\mathrm{P} 2_{1} / \mathrm{c}$ & 53.8 & 1493 \\
$\mathrm{NaAlH}_{4}$ & $\mathrm{R}-3$ & 54.0 & 1985 \\
$\mathrm{Na}_{2} \mathrm{LiAlH}_{6}$ & $\mathrm{I} 4_{1} / \mathrm{a}$ & 85.9 & 1559 \\
$\mathrm{Na}_{3} \mathrm{AlH}_{6}$ & $\mathrm{Fm}-3 \mathrm{~m}$ & 102.0 & 1578 \\
$\mathrm{Mg}_{2} \mathrm{NiH}_{4}$ & $\mathrm{P} 2_{1} / \mathrm{n}$ & 111.4 & 963 \\
$\mathrm{Mg}_{2} \mathrm{FeH}_{6}$ & $\mathrm{C} 2 / \mathrm{c}$ & 110.5 & 1455 \\
\hline
\end{tabular}

\subsection{Methodological Approach}

A comprehensive experimental and theoretical approach was adopted in order to achieve a fundamental knowledge of the HCR processes. Parallel experimental and computational activities have been carried on to investigate the thermodynamic, mechanistic and kinetic aspects of the reactions. 
This background could be the basis for the best optimization of hydrides in order to circumvent the weaknesses and develop their whole potential.

Many of the selected materials are commercially available (e.g., binary hydrides, borohydrides and alanates) and have been purchased and used as received or after a mechanochemical activation treatment. Mechanochemical treatments are complex processes that generally result in a number of different positive effects: (i) the particle size reduction; (ii) the breaking of the oxide layers; (iii) the induction of a high level of elastic shears and other stresses; and eventually, (iv) the formation of a stacking fault disorder; and (v) the increase of the atomic disorder [21]. For these reasons, as it is generally applied to activate hydrogen desorption, high energy ball milling was used to pretreat commercial hydrides. The general strategy adopted involved the milling of the commercial sample in stainless steel jars using stainless steel balls with a sample-to-ball mass ratio in the range 1:10-1:50. The exact milling conditions have been optimized for each hydride, as well as the composition of the pristine hydride mixture. In fact, also reactive milling between selected hydrides has been carried out in order to synthesize complex hydrides not available commercially. The evolution of the sample morphology and structure has been monitored by diffraction and electron microscopy. Furthermore, ball milling has been carried out also on a mixture of hydride and a high surface conductive carbon additive, Super $\mathrm{P}$, in order to promote the intimate mixing, as it is usually necessary for electrodic materials. In practice, the effect of milling and especially of its physico-chemical length resulted in being complex. While comminution is a general trend, certain hydrides undergo a huge pulverization and, in some cases, decomposition, especially in the presence of carbon. These huge morphological changes reflect differently on the electrochemical response and may result in the deterioration of the electrochemical activity.

Commercially unavailable hydrides were synthesized mainly by reactive ball milling or from metals by $\mathrm{H}_{2}$ sorption at moderate temperatures and high pressures.

The first step was the experimental verification of the ability of hydrides to give an HCR in a lithium cell with Li salt/organic carbonate electrolyte (materials screening). The typical thin film of the casting procedure has proven to be absolutely not indicated for hydride samples because of their high sensitivity to oxidation (and therefore, reactivity with any moisture or impurity contained in solvents). Due to the difficulty to produce and handle very thin pellets unless strongly pressed and therefore dense, the adopted strategy to produce suitable electrodes was to mildly press a thin layer of powder on a copper disk.

In parallel with electrochemical tests, computational simulations were carried out in order confirm the thermodynamic feasibility of the HCR and develop a reliable and detailed description of it. Ab initio calculations based on density functional theory (DFT) were performed to get structural and energy predictions at the atomistic level for all of the metal hydrides and metallic elements and the possible envisaged reactions in which they could be involved. The technical details of the used computational methods were discussed by us in [22-26]. The experimental capability or inability was then correlated to a robust physical-chemical characterization of the sample under investigation, i.e., to its purity, crystallinity and morphology, in order to evaluate a first possible optimization strategy.

Hydrides able to show a reversible electrochemical activity were studied further in depth with the aim to elucidate the reaction mechanism upon conversion (mechanism comprehension). In fact, although DFT calculations provide a theoretical description of the thermodynamically most favorable hydride conversion path, experimental evidences must be collected to elucidate the real process, which can largely deviate from predictions as a consequence of local overpotentials.

Electrochemical tests were combined with ex situ or in situ X-ray diffraction (XRD) experiments carried out on totally- or partially-discharged materials. Where possible, solid state nuclear magnetic resonance (NMR) analyses have been performed.

In parallel, computational simulations were deepened. The ultimate goal is to collect as much information as possible on the fundamental aspects of each reaction (e.g., structural changes, 
intermediate phase formation, solid solutions, size-depending effects, role of structural defects and surfaces) to provide fruitful feedbacks.

As a last point of the HCR mechanism characterization, also the nature of the typical conversion reaction drawbacks have been evaluated, paying particular attention to the irreversible capacity loss in the first cycle, the voltage hysteresis and the overpotentials. Ex situ scanning electron microscopy (SEM), transmission electron microscopy (TEM), Raman and infrared spectroscopies, as well as electrochemical impedance spectroscopy techniques were used on the most promising materials to fully characterize the growth and the nature of the solid electrode interphase (SEI) layer on the surface of the cycled electrodes, the active material morphology deterioration and the occurring of intercalation side-reactions.

The development of a reliable description of the HCR has been the basis for a critical assessment of the hydride-based electrodic material preparation (materials optimization trials), as well as for the evaluation of the improvement of the other cell components (electrochemical cell formulation assessment) and the final demonstration of a full Li-ion formulation (Li-ion-hydride proof of concept).

\section{Project Results and Achievements}

\subsection{Materials Screening}

\subsubsection{Simple Metal Hydrides}

On the basis of cost, environmental impact and expected theoretical capacity, the most interesting hydrides were identified to be $\mathrm{MgH}_{2}, \mathrm{NaH}, \mathrm{TiH}_{2}$ and $\mathrm{CaH}_{2}$. Their conversion reaction is expected to be the simplest displacement of the metal for lithium, according to:

$$
\mathrm{MHx}+\mathrm{xLi}^{+}+\mathrm{xe}^{-}=\mathrm{M}+\mathrm{xLiH} \text { with } \mathrm{x}=1 ; 2
$$

As purchased magnesium (AlfaAesar) and sodium (Aldrich) hydrides were crystalline, while titanium and calcium samples (both from Aldrich) have a rather amorphous fingerprint, with spare signals of the crystalline hydrides. All of them were tested as purchased and after a mechanochemical activation treatment. Table 1 (see the previous section) reports the estimated theoretical capacities for the simple hydrides, whereas in Table 2, the theoretical electro-motion force (emf) calculated at the DFT level at $0 \mathrm{~K}$ is summarized for the corresponding conversion reactions.

Table 2. DFT thermodynamic prediction for the hydride conversion reactions (HCR) of the simple hydrides.

\begin{tabular}{cc}
\hline Reaction & Theoretical Emf (V) \\
\hline $\mathrm{MgH}_{2}+2 \mathrm{Li}=\mathrm{Mg}+2 \mathrm{LiH}$ & 0.53 \\
$\mathrm{NaH}+\mathrm{Li}=\mathrm{Na}+\mathrm{LiH}$ & 0.43 \\
$\mathrm{TiH}_{2}+2 \mathrm{Li}=\mathrm{Ti}+2 \mathrm{LiH}$ & 0.15 \\
$\mathrm{CaH}_{2}+2 \mathrm{Li}=\mathrm{Ca}+2 \mathrm{LiH}$ & -0.02 \\
\hline
\end{tabular}

The electrochemical response of the $\mathrm{MgH}_{2}$ electrodes showed a first stable plateau at approximately $0.45 \mathrm{~V}$ vs. $\mathrm{Li}^{+} / \mathrm{Li}$, followed by a second plateau below $0.1 \mathrm{~V} \mathrm{vs.} \mathrm{Li}^{+} / \mathrm{Li}$. The first process, which led to a lithium loading of approximately 1.3-1.4 equivalents, was the HCR reaction, whereas the other processes below $0.2 \mathrm{~V} \mathrm{vs.} \mathrm{Li}^{+} / \mathrm{Li}$ were the lithium alloying reactions into the metallic magnesium lattice, as proven by us in ex situ XRD tests [17]. In the galvanostatic tests limited at $0.2 \mathrm{~V}$ in reduction (no alloying) shown in [17], a discharge capacity of $1600 \mathrm{mAh} \cdot \mathrm{g}^{-1}$, i.e., almost $80 \%$ of the theoretical capacity, was obtained in the first discharge and nearly $1000 \mathrm{mAh} \cdot \mathrm{g}^{-1}$ in the following recharge. The HCR experimental working electrode potential was in good agreement with our DFT calculations, which suggested a thermodynamic displacement potential of $0.53 \mathrm{~V}$ vs. $\mathrm{Li}^{+} / \mathrm{Li}$ [24]. This working potential and the corresponding adopted cycling voltage window in lithium 
cells $(0.2-2.5 \mathrm{~V})$ allow excluding the occurrence of lithium alloying into magnesium, which occurs at $\mathrm{V}<0.15 \mathrm{~V}$ vs. $\mathrm{Li}^{+} / \mathrm{Li}[13,17]$. The evolution of the $\mathrm{X}$-ray diffraction patterns of the four simple hydrides after $15 \mathrm{~h}$ of ball milling compared to the pristine materials is shown in Figure 2.

The ability of $\mathrm{MgH}_{2}$ to give a reversible electrochemical conversion reaction was demonstrated in 2008 by Tarascon [13]. Nevertheless, it was considered already in the materials screening (see above), as a benchmark, in order to set up our procedures, in terms of electrode and cell preparation. Pristine $\mathrm{MgH}_{2}$ was highly crystalline (tetragonal, $\mathrm{Pbcn}$ ) and presented as large aggregates of submicrometric particles, completely electrochemical inactive when used as electrode in a lithium cell. After $15 \mathrm{~h}$ of ball-milling, the material underwent significant particle breaking, and crystallites reduced to approximately $10-15 \mathrm{~nm}$. Further milling in the presence of Super P carbon successfully promoted the intimate mixing between the materials, producing carbon $/ \mathrm{MgH}_{2}$ aggregates, where the crystallites mean size was decreased to $5-8 \mathrm{~nm}\left(\mathrm{MgH}_{2} \mathrm{~B} 15 \mathrm{D} 5\right.$ sample). As expected, the electrochemical response was markedly affected and improved at each milling step. The experimental electrode potential profile measured upon electrochemical lithium loading in the PCGA (potentiodynamic cycling with galvanostatic acceleration) test is shown in Figure 3. In passing, it is very interesting to underline that the $\mathrm{MgH}_{2} \mathrm{~B}_{15 \mathrm{D} 5}$ sample that has been prepared by subsequent millings without and with a carbon source showed quite remarkable rate performances in a lithium cell, as shown by us in [17].

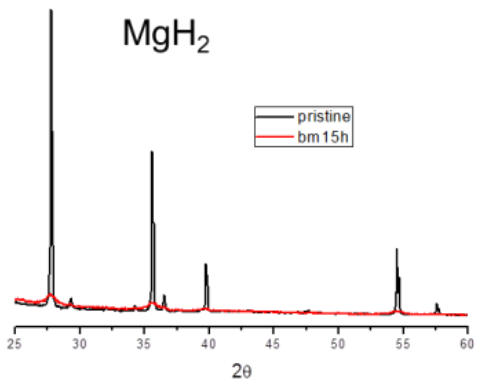

(a)

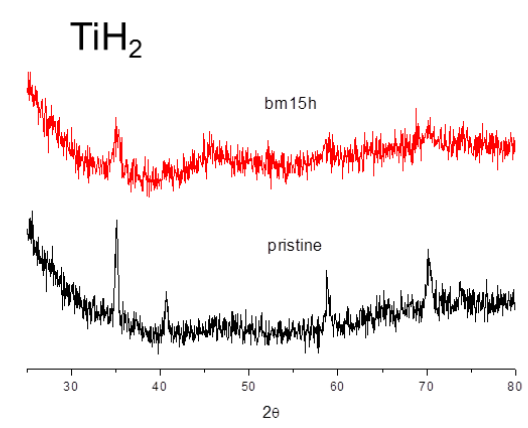

(c)

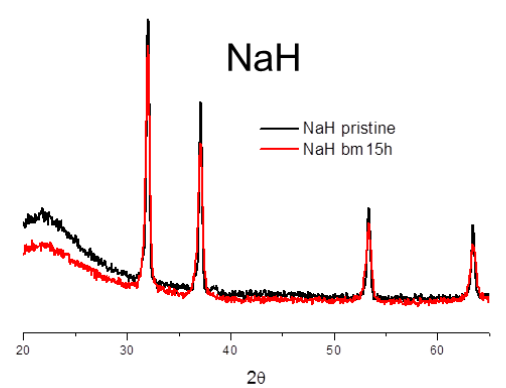

(b)

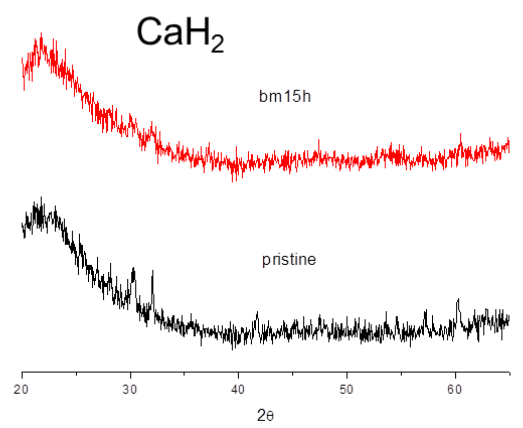

(d)

Figure 2. X-ray diffraction patters of the as-purchased (pristine) simple hydrides and after $15 \mathrm{~h}$ of ball milling: (a) $\mathrm{MgH}_{2}$; (b) $\mathrm{NaH}$; (c) $\mathrm{TiH}_{2}$ and (d) $\mathrm{CaH}_{2}$. CuK $\alpha$ radiation, step size 0.05 degrees, time/step $3 \mathrm{~s}$.

Like magnesium hydride, also as-purchased sodium hydride was highly crystalline (cubic Fm-3m), but contrary to the former, the latter was poorly affected by the mechanochemical treatment. Indeed, the only advantage achieved by milling was a good mixing with Super P. Nevertheless, sodium hydride was demonstrated to be highly electrochemically reactive with a delivered capacity corresponding to an almost complete conversion reaction. The reaction occurred mainly in a potential region below $0.3 \mathrm{~V}$ vs. Li, with only a minor contribution due to the electrolyte decomposition in the $0.8 \mathrm{~V}$ 
region. Unfortunately the recharge efficiency was less than $10 \%$. Apart from the poor experimental reversibility, DFT calculations immediately revealed the complexity of managing $\mathrm{NaH}$ cycling, the process appearing intrinsically irreversible. In fact, while $\mathrm{NaH}$ conversion to $\mathrm{Na}$ and $\mathrm{LiH}$ is expected to occur at $0.43 \mathrm{~V}$ vs. $\mathrm{Li}$, upon oxidation, the competition of the sodium stripping reaction is possible, which is expected at lower the potential ( $0.3 \mathrm{~V}$ vs. $\mathrm{Li}$ [27]). However, this competition is not the origin of the low recharge efficiency, which is more probably to be found in the high mechanical instability of the working electrode; nevertheless, it makes $\mathrm{NaH}$ conversion a non-reliable process for practical application.

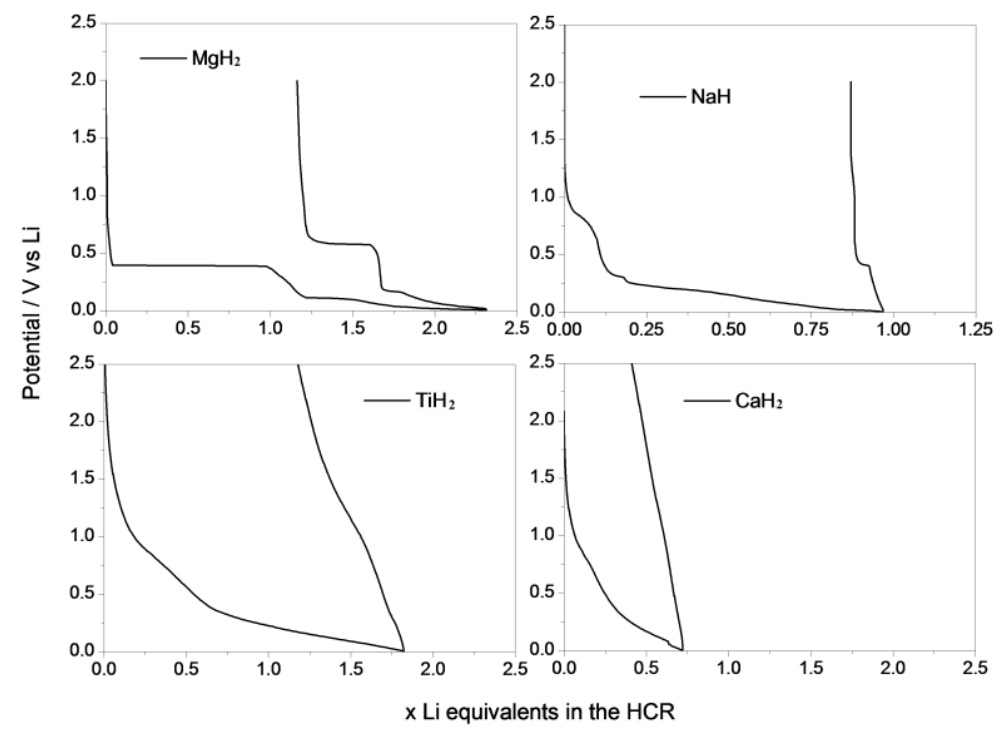

Figure 3. Electrode potential profiles upon electrochemical lithium loading and back conversion: (a) $\mathrm{MgH}_{2}$; (b) $\mathrm{NaH}$; (c) $\mathrm{TiH}_{2}$ and (d) $\mathrm{CaH}_{2}$. Galvanic chain: $\mathrm{Li} / \mathrm{LP} 30 /$ (AM 50\% carbon 30\% binder 20\%); AM = metallic hydride; LP30 = ethylene carbonate:dimethyl carbonate 1:1 v/v LiPF 1 molal. Voltage steps $10 \mathrm{mV}$, current cutoff at $50 \mathrm{mAh} \cdot \mathrm{g}^{-1}$.

Differently from the previous hydrides, pristine $\mathrm{TiH}_{2}$ was almost amorphous. The bare hydride, just hand mixed in a mortar with Super $P$, was found to be electroactive, capable of developing $62 \%$ of the theoretical capacity [28]. The potential profile suggested that part of this capacity, developing in the region $0.7-0.8 \mathrm{~V}$ vs. Li, was most likely due to electrolyte decomposition, but most of the process evolved below $0.15 \mathrm{~V}$ vs. Li, that is the conversion potential predicted by DFT. A short $(1 \mathrm{~h})$ milling treatment of the bare hydride activated the kinetics and allowed the complete conversion. A prolonged milling, or a second milling with Super $\mathrm{P}$, had the reverse effect of promoting some hydrogen desorption and therefore reducing the overall exchanged capacity. These effects on kinetics and on the hydrogen content were confirmed by hydrogen desorption analyses [28]. Achieved efficiency improved with carbon milling, but remained below $35 \%$, in the best case.

Furthermore, the purchased $\mathrm{CaH}_{2}$ resulted in being amorphous. Its electrochemical response was negative either as received or after mechanochemical treatments. Poor capacity developed upon discharge; most of it could be attributed to the electrolyte decomposition, and the residual was probably ascribable to the intrinsic lithium storage capability of Super P. A negligible oxidation process was observed. To confirm the absence of any lithium-driven displacement reaction, DFT evaluated as positive, i.e., $+3.2 \mathrm{~kJ} / \mathrm{mol}$, the energy variation associated with the $\mathrm{CaH}_{2}$ conversion to $\mathrm{Ca}+2 \mathrm{LiH}$, demonstrating that it is thermodynamically infeasible. 


\subsubsection{Borohydrides}

Borohydrides are polyanionic materials in which hydrogen is covalently bonded to central boron atoms in "complex" anions [18]. Thanks to their high hydrogen gravimetric densities, they are considered valuable candidates as hydrogen storage materials, even if high kinetic barriers seem to preclude their dehydrogenation and/or re-hydrogenation in the solid state. Nevertheless, recently, great research efforts have been made in the attempt to overcome them through catalytic doping, nano-engineering, additive destabilization and chemical modification [18]. On the other hand, if the kinetic stability of borohydrides to hydrogen desorption is a problematic issue in the hydrogen storage field, it could be an advantage in view of the possible application as electrodes in lithium-ion batteries, where the gas evolution would be a serious hazard [25]. Conceivable conversion reactions of borohydrides somehow remind of the thermal hydrogen desorption/adsorption processes, but differ in the final destination of hydrogen, which is not oxidized, but forms lithium hydride [25].

The borohydrides deserving most interest are those of alkaline or earth-alkaline metals, in particular: $\mathrm{LiBH}_{4}, \mathrm{NaBH}_{4}, \mathrm{KBH}_{4}, \mathrm{Ca}\left(\mathrm{BH}_{4}\right)_{2}$ and $\mathrm{Mg}\left(\mathrm{BH}_{4}\right)_{2}$. Thanks to their light weight, the complete conversion to metal elements and $\mathrm{LiH}$ is associated with a theoretical capacity ranging between 2 and $5 \mathrm{Ah} \cdot \mathrm{g}^{-1}$, as summarized in Table 1 (see the previous section). Preliminary DFT estimations demonstrated that all considered borohydrides can theoretically be fully converted in a lithium cell to metals and $\mathrm{LiH}$ [25]. This could occur through a single step process $\left(\mathrm{M}\left(\mathrm{BH}_{4}\right)_{\mathrm{x}}+4 \mathrm{xLi}=\mathrm{M}+\mathrm{xB}+4 \mathrm{xLiH}\right)$ or in two steps $\left(\mathrm{M}(\mathrm{BH} 4)_{\mathrm{x}}+3 \mathrm{xLi}=\mathrm{MHx}+\mathrm{xB}+3 \mathrm{xLiH}\right.$ and $\left.\mathrm{MHx}+\mathrm{xLi}=\mathrm{M}+\mathrm{xLiH}\right)$. DFT thermodynamic predictions suggested the most convenient thermodynamic path for each borohydride, but remarkable alterations could occur due to possible overvoltages. All materials were commercially available. Morphological and structural features were largely different for the various borohydrides. XRD analyses and TEM confirmed the phase purity and the crystallinity of $\mathrm{Li}, \mathrm{Na}$ and $\mathrm{K}$ borohydrides, whereas revealing the phase mixture of two poorly crystalline allotropes for the $\mathrm{Ca}\left(\mathrm{BH}_{4}\right)_{2}$ and the almost amorphous character of $\mathrm{Mg}\left(\mathrm{BH}_{4}\right)_{2}$. Mechanochemical treatments were able to pulverize the $\mathrm{Na}$ and $\mathrm{K}$ borohydrides particles. On the other hand, mechanical grinding had apparently had negligible effects on LiBH4 and led to a complete loss of any crystallinity in the case of $\mathrm{Ca}$ and $\mathrm{Mg}$ borohydrides. In the case of $\mathrm{K}, \mathrm{Mg}$ and $\mathrm{Ca}$ borohydrides, milling with carbon promoted the formation of large homogeneous aggregates where the hydrides and the Super $\mathrm{P}$ could be hardly recognized, in particular for $\mathrm{Mg}\left(\mathrm{BH}_{4}\right)_{2}$. The electrochemical response of borohydrides in lithium cells experimentally showed some electroactivity only for $\mathrm{NaBH}_{4}$ and $\mathrm{Mg}\left(\mathrm{BH}_{4}\right)_{2}$, as summarized in Table 3.

Table 3. Electrochemical activity in lithium cells of the studied borohydrides.

\begin{tabular}{|c|c|c|c|c|c|}
\hline Hydride & $\begin{array}{l}\text { Theoretical } \\
\text { Capacity } \\
\left(\mathrm{mAh} \cdot \mathrm{g}^{-1}\right)\end{array}$ & $\begin{array}{l}\text { Ball } \\
\text { Milling } \\
\text { Time } \\
\text { (hours) }\end{array}$ & $\begin{array}{c}\text { Ball Milling Time with } \\
\text { Carbon (5:3 Ratio between } \\
\text { Borohydride and Carbon) } \\
\text { (hours) }\end{array}$ & $\begin{array}{l}\text { First } \\
\text { Discharge } \\
\text { Capacity } \\
\left(\mathrm{mAh} \cdot \mathrm{g}^{-1}\right)\end{array}$ & $\begin{array}{c}\text { Li Equivalents } \\
\text { Incorporated in PCGA } \\
\text { Tests (First Discharge) }\end{array}$ \\
\hline $\mathrm{LiBH}_{4}$ & 4992 & 15 & 5 & 52 & 0.04 \\
\hline $\mathrm{NaBH}_{4}$ & 2834 & $\begin{array}{c}1 \\
15 \\
\end{array}$ & $\begin{array}{l}\frac{1}{2} \\
5 \\
\end{array}$ & $\begin{array}{c}74 \\
211 \\
\end{array}$ & $\begin{array}{l}0.10 \\
0.30\end{array}$ \\
\hline $\mathrm{KBH}_{4}$ & 1987 & 15 & 5 & 66 & 0.13 \\
\hline $\mathrm{Mg}\left(\mathrm{BH}_{4}\right)_{2}$ & 3971 & $\begin{array}{c}1 \\
15\end{array}$ & $\begin{array}{l}\frac{1}{2} \\
5\end{array}$ & $\begin{array}{l}539 \\
205\end{array}$ & $\begin{array}{l}1.09 \\
0.41\end{array}$ \\
\hline $\mathrm{Ca}\left(\mathrm{BH}_{4}\right)_{2}$ & 3074 & 15 & 5 & 9 & 0.003 \\
\hline
\end{tabular}

In general, in all cases, the delivered capacities were very small, but tunable by altering the samples' morphology. The best electrochemical activity was obtained for samples with small and poorly-aggregated crystalline particles $[23,25]$. Apparently, only the magnesium borohydride showed some appreciable reversible electrochemical activity. 


\subsubsection{Alanates}

Alanates (also called aluminohydrides) are complex hydrides consisting of $\mathrm{AlH}_{4}$ tetrahedra or $\mathrm{AlH}_{6}$ octahedra, negatively charged, surrounded by metal cations [18]. Alkali metal aluminohydrides are ionic-covalent compounds, in which $\mathrm{Al}-\mathrm{H}$ are covalent bonds and form polyanions collecting the negative charge. The negative charge of the anions is compensated by cations, e.g., $\mathrm{Li}^{+} \mathrm{Or} \mathrm{Na}^{+}[28]$, and $\left(\mathrm{M}^{+}-\left[\mathrm{AlH}_{4}\right]^{-}\right)$and $\left(3 \mathrm{M}^{+}-\left[\mathrm{AlH}_{6}\right]^{3-}\right)$ are ionic bonds [18].

Like borohydrides, the alanate family promises very interesting capacities due to the light molar weight of aluminum and the high hydrogen content. In fact, in view of a full conversion reaction in $\mathrm{LiH}$ and metal elements, they can theoretically achieve up to $2 \mathrm{Ah} \cdot \mathrm{g}^{-1}$ exchanging at least three electrons for the redox center as summarized in the Table 1 (see the previous section).

The alanates selected for investigation were lithium and sodium aluminum tetrahydride, i.e., $\mathrm{LiAlH}_{4}$ and $\mathrm{NaAlH}_{4}$, and aluminum hexahydride, i.e., $\mathrm{Li}_{3} \mathrm{AlH}_{6}, \mathrm{Na}_{3} \mathrm{AlH}_{6}$ and $\mathrm{LiNa}_{2} \mathrm{AlH}_{6}$. While the first ones were commercially available, the latter were synthesized by mechanochemistry $[22,26]$. Furthermore, in this case, DFT was used to preliminarily verify the thermodynamic feasibility of alanates' conversion $[22,26]$.

From the experimental point of view, as-received $\mathrm{LiAlH}_{4}$ and $\mathrm{NaAlH}_{4}$ demonstrated a very promising electrochemical lithium loading ability without the need for any mechanochemical pre-activation, being able to develop almost all of the theoretical capacity expected for complete conversion reactions. In order to improve their poor re-charge efficiency (10 and 30\%, respectively), mechanochemical treatments were performed. Milling produced the expected particle reduction and compositing with carbon; nevertheless, especially the milling step with carbon brought some hydrogen desorption. Optimizing milling time allowed reaching a recharge efficiency equal to $39 \%$ in the case of $\mathrm{LiAlH}_{4}$ and more than $70 \%$ for $\mathrm{NaAlH}_{4}$, but cyclability remained unsatisfactory for both alanates $[22,26]$.

Hexahydrides were successfully synthesized by ball milling proper amounts of tetrahydrides, $\mathrm{LiH}$ and/or $\mathrm{NaH}[22,26]$. TEM observation revealed large micrometric round-shaped particles with smooth surfaces and low phase contrast on the particle edges, which from an XRD Rietveld analysis are composed by 30-40-nm average size of crystallites. Electrodes were prepared and tested in lithium cells, obtaining interesting discharge profiles. In the case of $\mathrm{LiNa}_{2} \mathrm{AlH}_{6}$, the full theoretical capacity, i.e., $1.87 \mathrm{Ah} \cdot \mathrm{g}^{-1}$, was delivered upon discharge with nearly $40 \%$ recharge efficiency [22].

\subsubsection{Other Complex Hydrides}

Besides borohydrides and alanates, several other complex hydrides have been evaluated for hydrogen storage. In consideration of the above-mentioned selection criteria, the study was focused on $\mathrm{Mg}_{2} \mathrm{NiH}_{4}$ and $\mathrm{Mg}_{2} \mathrm{FeH}_{6}$, which offer theoretical capacities of 963 and $1455 \mathrm{mAh} \cdot \mathrm{g}^{-1}$, respectively. They were prepared by mechanochemistry. Pure $\mathrm{Mg}_{2} \mathrm{NiH}_{4}$ was obtained milling Ni with a slight excess of $\mathrm{MgH}_{2}$; on the contrary, $\mathrm{Mg}_{2} \mathrm{FeH}_{6}$ synthesis was never complete and much more complicated, since it requires $\mathrm{H}_{2}$ atmosphere and preferably post milling treatments of high temperature hydrogen desorption/sorption in a Sievert apparatus [29]. The electrochemical response shown in Figure 4 of magnesium-based complex hydrides in a lithium cell did not differ much from that of $\mathrm{MgH}_{2}$.

Hydrides conversion occurred in a similar potential range $(<0.5 \mathrm{~V}$ vs. Li in discharge, $>0.5 \mathrm{~V}$ vs. $\mathrm{Li}$ in charge), almost reaching the theoretical lithium loading upon conversion for both $\mathrm{Mg}_{2} \mathrm{NiH}_{4}$ and $\mathrm{Mg}_{2} \mathrm{FeH}_{6}$, i.e., four and six equivalents, respectively, above $0.2 \mathrm{~V}$ vs. $\mathrm{Li}$ in reduction. As expected, at lower potentials below $0.2 \mathrm{~V}$ vs. $\mathrm{Li}$, also the alloying of $\mathrm{Li}$ into the metal lattice of $\mathrm{Mg}$ occurred. In terms of specific capacities, $\mathrm{Mg}_{2} \mathrm{NiH}_{4}$ and $\mathrm{Mg}_{2} \mathrm{FeH}_{6}$ supplied upon reduction 1588 and $2644 \mathrm{mAh} \cdot \mathrm{g}^{-1}$ compared to $2342 \mathrm{mAh} \cdot \mathrm{g}^{-1}$ for the $\mathrm{MgH}_{2}$ benchmark in the PCGA tests shown in Figure 3, with a potential cutoff of $0.01 \mathrm{~V}$ vs. Li. In charge, the two complex Mg-based hydrides were able to supply 650 and $800 \mathrm{mAh} \cdot \mathrm{g}^{-1}$ for the $\mathrm{Mg}_{2} \mathrm{NiH}_{4}$ and $\mathrm{Mg}_{2} \mathrm{FeH}_{6}$, respectively, compared to $1171 \mathrm{mAh} \cdot \mathrm{g}^{-1}$ for the $\mathrm{MgH}_{2}$ benchmark. Compared to magnesium hydride, negligible improvements are observed in terms of voltage hysteresis or coulombic efficiency. In summary, beneath close to 
theoretical values, the reversible specific capacities obtained in $\mathrm{Mg}_{2} \mathrm{NiH}_{4}$ and $\mathrm{Mg}_{2} \mathrm{FeH}_{6}$ discharges were lower than for $\mathrm{MgH}_{2}$.

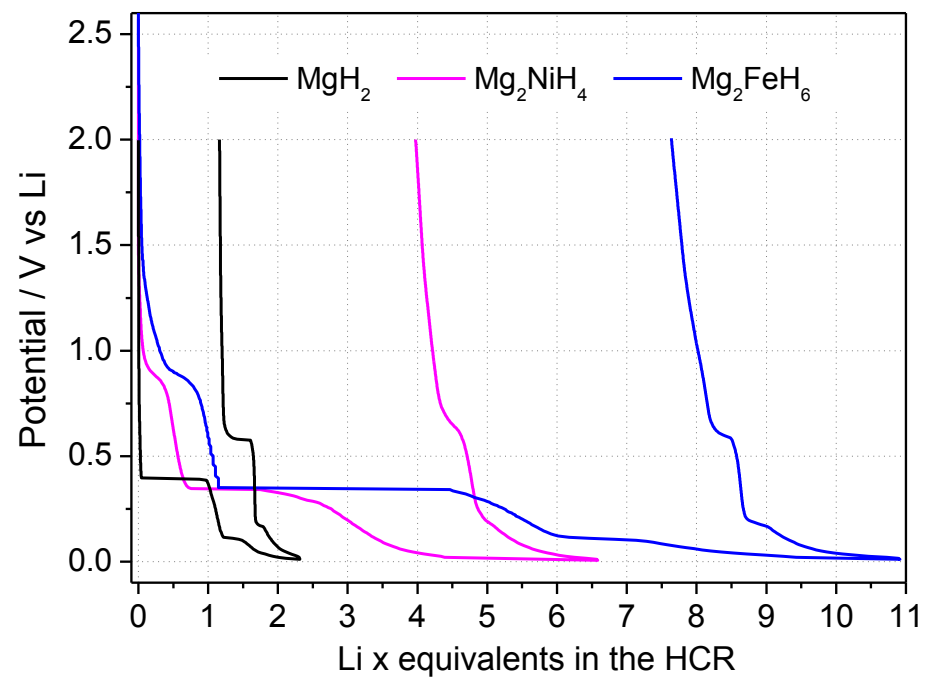

Figure 4. Electrode potential profiles upon electrochemical lithium loading in PCGA tests for $\mathrm{Mg}_{2} \mathrm{NiH}_{4}, \mathrm{Mg}_{2} \mathrm{FeH}_{2}$ compared to $\mathrm{MgH}_{2}$. Galvanic chain: Li/LP30/ (AM 50\% carbon 30\% binder $20 \%) ; \mathrm{AM}=$ metallic hydride; $\mathrm{LP3} 0$ = ethylene carbonate:dimethyl carbonate 1:1 v/v LiPF 1 molal. Voltage steps $10 \mathrm{mV}$, current cutoff at $50 \mathrm{~mA} \cdot \mathrm{g}^{-1}$.

\subsection{Mechanism Comprehension}

Electrochemical methods are in principle powerful tools to study redox systems. They could provide a description of redox processes by distinguishing reaction steps, giving the indication of the potential where they occur and of the number of electrons (and lithium equivalents) involved. Unfortunately, in real systems, undesired side reactions can take place, while kinetics problems can lead to incorrect evaluation of processes, convoluting them or completely hindering reactions. Therefore, the use of the simple electrochemical techniques is generally not enough to describe complex processes like conversion $[13,17,22,26]$.

In order to identify and decouple the possible competitive phenomena occurring upon lithium incorporation into electrodes, a possible strategy can exploit the synergic use of DFT and complementary experimental techniques [30-37].

DFT could provide an estimation of the thermodynamic feasibility of conversion processes and estimate the potential vs. Li where reactions should occur [17]. Indeed the mechanism can be modeled at an atomic level, and a description of the most convenient thermodynamic path can be obtained at several levels of detail $[22,26]$. The occurrence of multistep reactions, with the formation of more or less stable intermediates is forecast, but it is even possible to describe the atom movements at the reactive surfaces [38].

Still, the correspondence between thermodynamic evaluations and experimental electrochemical results can be questionable. In the case of $\mathrm{MgH}_{2}$, the development of the electrochemical process in a potential range close to DFT estimation is certainly a good indication $[17,24]$. Unfortunately, this is not the case of the other hydrides under consideration, for which the experimental reaction potential largely deviates from the computed one $[22,23,25,26]$. Kinetics limitations are generally the origin of such differences [38], and they can also subvert the order of the reactions in a multistep process, thus modifying the supposed path.

As a consequence, other experimental techniques must be combined with electrochemical tests and DFT in order to univocally describe complex processes like displacement reactions [30]. The most useful is certainly XRD, either ex situ or in situ, with the only limitation that can be applied only to 
crystalline materials. Therefore, wherever possible and valuable, a comprehensive study has been carried on in order to precisely identify the reaction mechanism.

In the frame of this project, we carried out detailed multi-techniques studies for $\mathrm{MgH}_{2}$ [17] and for alanates $[22,26]$ aimed at identifying and decouple the different reaction mechanism upon the electrochemical incorporation and de-incorporation of lithium.

The combination of ex situ X-ray powder diffraction, transmission electron microscopy and DFT calculation proved that $\mathrm{MgH}_{2}$ converts to give $\mathrm{Mg}$ and $\mathrm{LiH}$ without the formation of any stable intermediate bulk phase like $\mathrm{LiMgH}_{3}$ or $\mathrm{Li}_{2} \mathrm{MgH}_{4}$, but with the possible occurrence of a metastable $\mathrm{Li}_{x} \mathrm{Mg}_{1-\mathrm{x}} \mathrm{H}_{2-\mathrm{x}}$ solid solution. In fact, upon lithium incorporation into the electrode, it was possible to observe that the $\mathrm{MgH}_{2}$ diffraction peaks' position slightly shift, indicating a certain lattice contraction. Alloying of $\mathrm{Li}$ in hcp Mg can take place before the end of conversion, while at a deep state of discharge, there is the formation and lithium enrichment of a bcc Li-Mg solid solution. Our results were in excellent agreement with the available literature [13].

The same set of techniques was exploited to study the lithium and sodium alanates' conversion process [22].

For $\mathrm{LiAlH}_{4}$, potential profiles collected upon electrochemical lithium incorporation exhibited at least three plateaus, namely at $0.78,0.27$ and $0.15 \mathrm{~V}$ vs. Li. DFT predictions summarized in Table 4, confirmed that, from a thermodynamic point of view, the HCR process occurs in a three-step path involving the formation of $\mathrm{Li}_{3} \mathrm{AlH}_{6}$ at $0.86 \mathrm{~V}$ vs. $\mathrm{Li}$ and its following conversion to $\mathrm{LiH}$ and $\mathrm{Al}$ at $0.74 \mathrm{~V}$, while the final process could be Li alloying into Al.

Table 4. DFT thermodynamic minimal-energy path prediction for the HCR multistep processes of the lithium and sodium alanates. emf, electro-motion force.

\begin{tabular}{|c|c|}
\hline Reaction & Theoretical Emf (V) \\
\hline $2 \mathrm{NaAlH}_{4}+3 \mathrm{Li}=\mathrm{LiNa}_{2} \mathrm{AlH}_{6}+2 \mathrm{LiH}+\mathrm{Al}$ & 0.73 \\
\hline $3 / 2 \mathrm{LiNa}_{2} \mathrm{AlH}_{6}+3 / 2 \mathrm{Li}=3 \mathrm{LiH}+1 / 2 \mathrm{Al}+\mathrm{Na}_{3} \mathrm{AlH}_{6}$ & 0.66 \\
\hline $\mathrm{Na}_{3} \mathrm{AlH}_{6}+3 \mathrm{Li}=3 \mathrm{NaH}+\mathrm{Al}+3 \mathrm{LiH}$ & 0.61 \\
\hline $\mathrm{NaH}+\mathrm{Li}=\mathrm{Na}+\mathrm{LiH}$ & 0.43 \\
\hline $3 \mathrm{LiAlH}_{4}+6 \mathrm{e}+6 \mathrm{Li}^{+} \rightleftarrows \mathrm{Li}_{3} \mathrm{AlH}_{6}+2 \mathrm{Al}+6 \mathrm{LiH}$ & 0.86 \\
\hline $\mathrm{Li}_{3} \mathrm{AlH}_{6}+3 \mathrm{e}+3 \mathrm{Li}^{+} \rightleftarrows 6 \mathrm{LiH}+\mathrm{Al}$ & 0.74 \\
\hline $\mathrm{Al}+\mathrm{Li} \rightleftarrows \mathrm{AlLi}$ & 0.29 \\
\hline
\end{tabular}

The simple qualitative comparison between the calculated and experimental reaction potentials suggests that large overpotentials occurred, and therefore, the final confirmation of the true HCR process could be only provided by ex situ XRD on discharged electrodes. This analysis highlighted the formation of $\mathrm{Li}_{3} \mathrm{AlH}_{6}$ as the reaction intermediate and the final $\mathrm{Li}-\mathrm{Al}$ alloying. Moreover, ex situ XRD further suggested the irreversibility of the HCR process and the inability to convert back to $\mathrm{LiAlH}_{4}$ from $\mathrm{Li}_{3} \mathrm{AlH}_{6}$.

Very detailed information about the sodium alanates family has been obtained by joining in situ X-ray powder diffraction and solid state NMR with electrochemical and computational studies [22,39]. Several possible lithium incorporation redox reactions have been modeled by DFT, including the formation of $\mathrm{LiNa}_{2} \mathrm{AlH}_{6}, \mathrm{Na}_{3} \mathrm{AlH}_{6}$ and $\mathrm{NaH}$ before the complete reduction to $\mathrm{LiH}$ and metallic $\mathrm{Na}$ as reported in Table 4. Calculations suggested that the most convenient thermodynamic path proceeds at least in four steps, with the first formation of $\mathrm{LiNa}_{2} \mathrm{AlH}_{6}$, its conversion to $\mathrm{Na}_{3} \mathrm{AlH}_{6}$, the reduction to $\mathrm{NaH}$ and its final displacement by $\mathrm{Li}$ to produce $\mathrm{Na}$ and $\mathrm{LiH}$. At the same time, DFT evidenced how other reactions could occur at the same time as the effect of overvoltages. In particular, $\mathrm{NaAlH}_{4}$ could convert directly to $\mathrm{Na}_{3} \mathrm{AlH}_{6}$ or even to $\mathrm{NaH}$. As a matter of fact, the four steps figured by calculation did not fit with the three steps highlighted in the experimental discharge potential profile, where reactions developed at much lower potential than expected (i.e., $0.41,0.26$ and $0.17 \mathrm{~V} \mathrm{vs.} \mathrm{Li).} \mathrm{The} \mathrm{in} \mathrm{situ} \mathrm{XRD}$ analyses allowed observing in real time the evolution of the involved phases and determining the 
effective conversion path. The discharge of electrodes based on $\mathrm{NaAlH}_{4}, \mathrm{LiNa}_{2} \mathrm{AlH}_{6}$ and $\mathrm{Na}_{3} \mathrm{AlH}_{6}$ was observed separately. It was verified that $\mathrm{NaAlH}_{4}$ reduction to $\mathrm{LiNa}_{2} \mathrm{AlH}_{6}$ and $\mathrm{Na}_{3} \mathrm{AlH}_{6}$ is competitive. $\mathrm{LiNa}_{2} \mathrm{AlH}_{6}$ firstly formed at higher potential, but $\mathrm{Na}_{3} \mathrm{AlH}_{6}$ appeared before $\mathrm{NaAlH}_{4}$ is fully converted. In situ XRD studies of the hexahydrides reduction in lithium cells demonstrated that there is no interconversion between one and the other, but both of them are reduced directly to metallic $\mathrm{Na}$ and $\mathrm{LiH}$. Therefore, $\mathrm{Na}_{3} \mathrm{AlH}_{6}$ is a direct product of $\mathrm{NaAlH}_{4}$ reduction. $\mathrm{NaH}$ intermediate is never observed. At the discharge cutoff potential, $\mathrm{NaAlH}_{4}$ peaks had completely disappeared; $\mathrm{Na}$ and $\mathrm{Al}$ peaks were intense, but the process was not complete because hexahydrides conversion was not completed. Oxidation was also followed in situ, and it was surprisingly found that $\mathrm{NaAlH}_{4}$ was re-formed back. This result is remarkable in consideration that, as mentioned above, once metallic sodium is formed, its stripping should be thermodynamically more convenient than its reaction to re-produce $\mathrm{NaH}$ or any alanate.

Additional confirmations were obtained by solid state NMR experiments performed ex situ on electrodes at different states of charge [39]. $\mathrm{Na}^{23} \mathrm{NMR}$ analyses were carried out on both a pristine alanate electrode and on a carbon-milled $\mathrm{NaAlH}_{4}$ one. The above-mentioned conversion intermediates were all identified, but particularly interesting were the spectra of the recharged electrodes. The composite electrode, with its $70 \%$ of recharge efficiency, was actually composed of a mixture of alanates, with a dominance of $\mathrm{NaAlH}_{4}$. The bare alanate-based electrode, with a recharge efficiency of only $30 \%$, still contained a huge amount of metallic sodium in its recharged state. Clearly, the Na stripping suffers from very high overpotentials that allow sodium to participate in hydride reformation.

\subsection{Materials Optimization Trials}

At least two hydrides have been identified as valuable candidates for being applied as the negative electrode in lithium ion batteries, yet their poor cycle life is an important obstacle. The conversion processes entail massive structural reorganization and volumetric changes (for instance, $72 \%$ for $\mathrm{NaAlH}_{4}$ ). These changes can lead to particle isolation and cracking as a result of electrode grinding and to a subsequent fading of the capacity after a few cycles. Attempts to address this issue through electrode engineering have been made for conversion reaction materials, using a number of strategies, such as forming nanocomposites with nanoporous carbon [12].

Confinement strategies are commonly used in the design of hydrogen storage materials, like metal hydrides [40,41]. Besides preserving conductivity, the presence of carbon is beneficial towards preventing grain growth and sintering by limiting the large volumetric changes encountered during lithium incorporation/de-incorporation [9]. Along these lines, in order to improve the performances of hydrides in electrochemical cells, the possibility to confine $\mathrm{MgH}_{2}$ and $\mathrm{NaAlH}_{4}$ particles in mesoporous or nanometric carbon host matrices was investigated. Namely, nanocomposites based on (a) $\mathrm{MgH}_{2}$ on SuperP carbon and (b) $\mathrm{NaAlH}_{4}$ and a pyrolyzed resorcinol-formaldehyde carbon aerogel (CA) were prepared. All of the nanoconfined samples have been produced and manipulated in air-safe Ar-filled glove boxes to avoid moisture contact and degradation.

The nanocomposite Mg-carbon sample has been obtained by impregnating a $1 \mathrm{M}$ solution of di-N-butyl-magnesium in heptane with Super-P carbon nanoparticles (SP-C) to a final nominal Mg:C molar ratio of 1:4. The solvent has been evaporated gently at room temperature. The impregnated powder has been transferred into quartz liner and sealed in a stainless-steel reactor. The reactor has been heated to $400{ }^{\circ} \mathrm{C}$ for three hours, and then, the final Mg@SP-C composite sample recuperated and stored in the glove box. The TEM micrographs of the Mg@SP-C composite material is shown in Figure 5 compared to the pristine SP sample.

The magnesium nanoparticles $2-5 \mathrm{~nm}$ in size nicely decorate the surface of the SP-C round-shaped nanoparticles (20-30 nm in size). The decoration is apparently homogeneous throughout the entire sample. 
The hydrogenation of the Mg@SP-C sample to give the Mg@SP-C@ $\mathrm{H}_{2}$ has been obtained in a Sievert apparatus at $120^{\circ} \mathrm{C}$ under 20 bars of $\mathrm{H}_{2}$ for $24 \mathrm{~h}$.
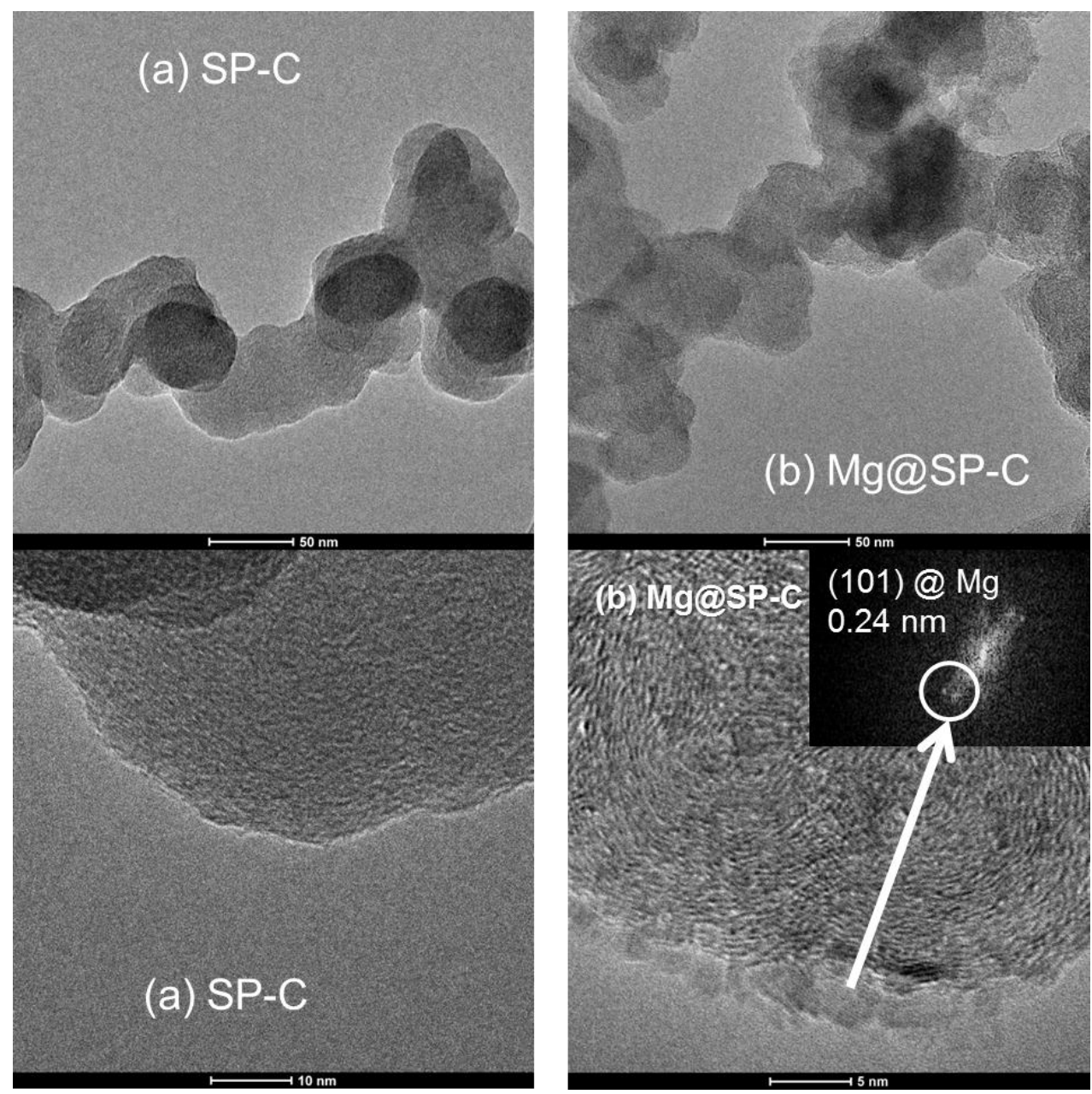

Figure 5. TEM micrographs of the SP-C (a) and Mg@SP-C (b) samples. In the figure b inset the selected area electronic diffraction pattern is reported.

The XRD diffraction pattern is shown in the Figure 6.

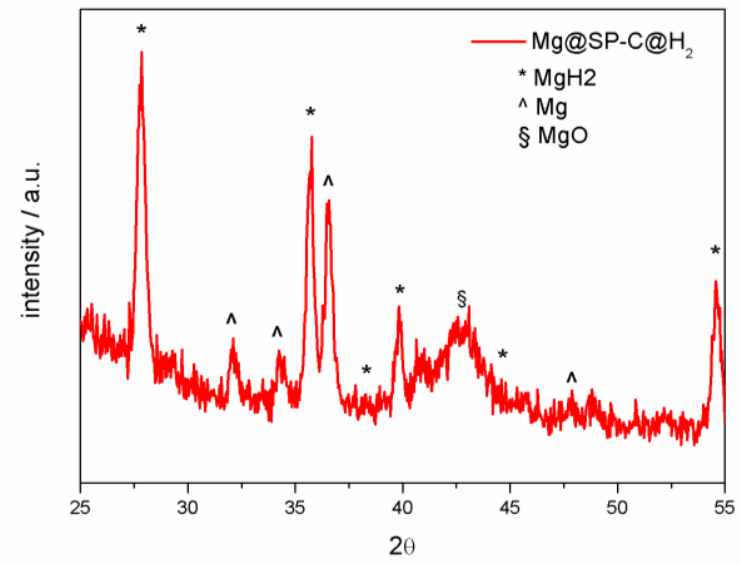

Figure 6. XRD pattern of the $\mathrm{Mg} @ S \mathrm{SP}-\mathrm{C} @ \mathrm{H}_{2}$ sample. $\mathrm{CuK} \alpha$ radiation, step size 0.05 degrees, time/step $3 \mathrm{~s}$. 
Apparently, the transformation of $\mathrm{Mg}$ to $\mathrm{MgH}_{2}$ is not complete, but longer hydrogenation steps only marginally improve the phase transition. Minor traces of $\mathrm{MgO}$ contamination were also detected.

This composite material shows very promising performance in lithium cells in terms of reversible specific capacity and cycling ability in galvanostatic tests, as reported in Figure 7.

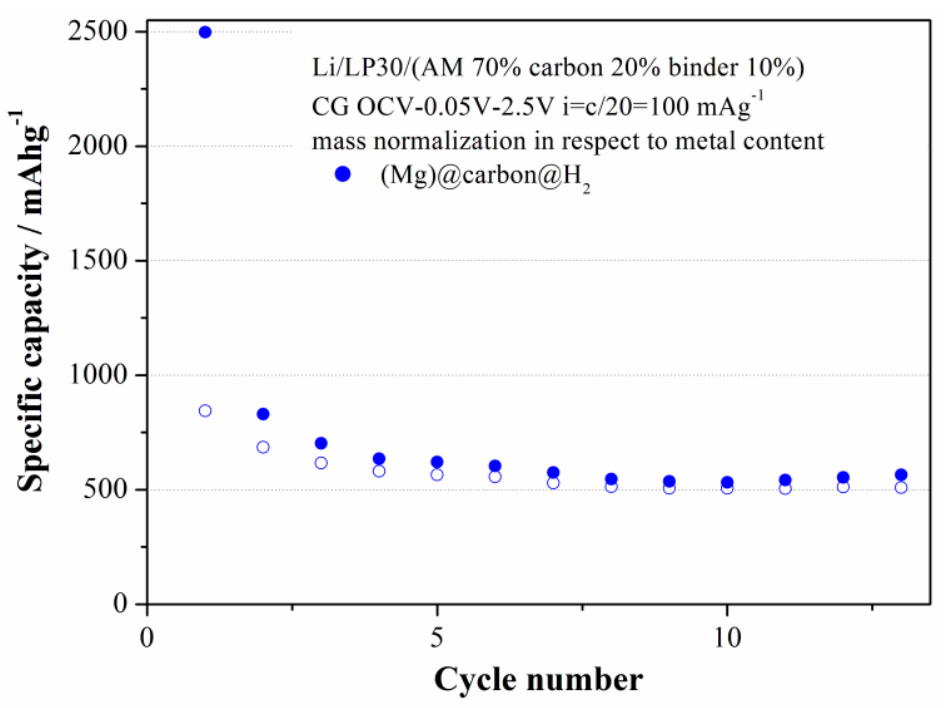

Figure 7. Galvanostatic cycling in lithium cells of the Mg@SP-C@ $\mathrm{H}_{2}$ sample. LP30 = ethylene carbonate:dimethyl carbonate $1: 1 \mathrm{v} / \mathrm{v} \mathrm{LiPF}_{6} 1$ molal.

The final specific capacities are comparable with analogue performances demonstrated in the literature by Latroche and co-workers [42]. In passing, it should be mentioned that the possible contribution of the SP-C carbon to the overall capacity is below $100 \mathrm{mAh} \cdot \mathrm{g}^{-1}$.

Turning to nanoconfined sodium alanate, a solvent-assisted infiltration method was chosen to highly disperse the hydride, as well as facilitate a close contact with the carbon material [43]. The synthesized sample was a nanocomposite material with a homogeneous morphology consisting of alanate particles permeated into the carbon matrix [43]. Nevertheless, the resulting nanoconfined material was highly reactive and therefore complex to handle: it easily burns upon exposure to air and starts to desorb hydrogen already below $100{ }^{\circ} \mathrm{C}$. Furthermore, despite elemental analysis performed on carbon revealing just $1.75 \mathrm{wt} \%$ of residual oxygen, the chemical interaction between alanate and carbon is large. Both FTIR and solid state NMR analyses revealed rather an alanate oxidation, and thermal analysis demonstrated that only $54 \%$ of the total infiltrated hydride was preserved after confinement. Despite these issues, such a nanocomposite demonstrated improved cyclability in a lithium cell, being capable at the 10th discharge to deliver $37 \%$ of the capacity provided in the first cycle.

Apparently, confinement of both $\mathrm{MgH}_{2}$ and $\mathrm{NaAlH}_{4}$ is effective at reducing electrode pulverization upon cycling due to the huge volume variations occurring upon HCR.

Despite infiltration into a carbon matrix appearing to be a promising method to exploit the hydrides' electrochemical potentialities, the optimization of the infiltration methods is necessary in order to maximize the magnesium hydrogenation and avoid the decomposition of the alanate during the synthesis. Further improvements might be obtained by optimizing the solvent-assisted infiltration method, for instance by improving the solvent purity, increasing carbon porosity and grinding under a reducing hydrogen atmosphere (by ball milling in closed anaerobic vials). Furthermore, the use of alternative melt infiltration techniques should be explored. 


\subsection{Electrochemical Cell Formulation Assessment}

Another important aspect to consider in order to improve the electrochemical performances of hydrides regards their chemical reactivity towards the common solvents used in non-aqueous electrolytes.

The effect on the electrochemical performances of the use of a variety of electrolytes was tested with respect to $\mathrm{MgH}_{2}$-based electrodes $\left(\mathrm{MgH}_{2} \_\right.$B15D5 sample) in lithium cells. We screened (i) three liquid electrolyte systems, i.e., ethylene carbonate:dimethyl carbonate $1: 1 \mathrm{v} / \mathrm{v} \mathrm{LiPF} 6$ 1 molal (LP30), ethylene carbonate:dimethyl carbonate 1:1 v/v Li triflate 1 molal (EC:DMC LiTf), 1,3-dioxolane:dimethoxyethane 1:1 v/v Li triflate 1 molal (DOL:DME LiTf), (ii) an ionic liquid added electrolyte, i.e., LP30:N-n-butyl-N-methylpyrrolidinium hexafluorophosphate $\left(\left[\mathrm{Py}_{14}\right] \mathrm{PF}_{6}\right) 7: 3$, and (iii) a polymer-based electrolyte constituted by LiTFSI dissolved in a polyethylene-oxide (MW 100,000) mixed with $5 \%$ of $\mathrm{SiO}_{2}\left(\mathrm{PEO}_{20} \mathrm{LiTFSI}\right)$. The electrochemical responses are shown in Figure 8 for liquid electrolytes, in Figure 9 for the ionic liquid and in Figure 10 for the polymeric system.
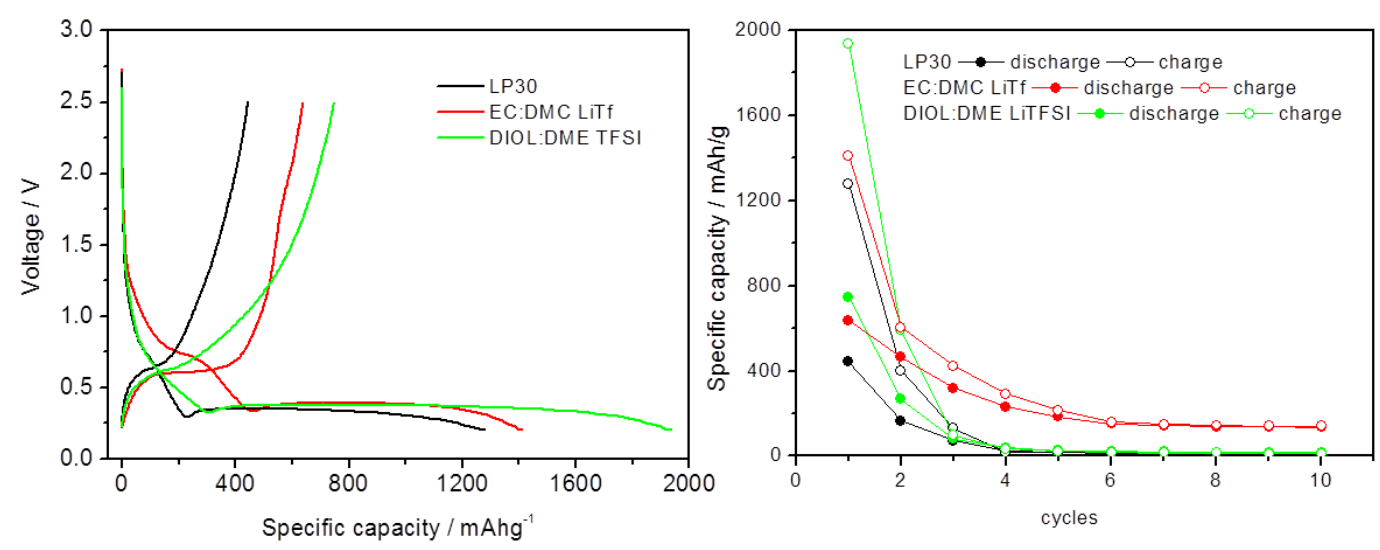

Figure 8. Galvanostatic cycling in lithium cells of $\mathrm{MgH}_{2} \_\mathrm{B} 15 \mathrm{D} 5$ electrodes in different liquid electrolytes. Galvanic chain: Li/electrolyte/(AM 50\% carbon 30\% binder 20\%); AM = metallic hydride; LP30 = ethylene carbonate:dimethyl carbonate $1: 1 \mathrm{v} / \mathrm{v} \mathrm{LiPF}_{6} 1$ molal. Current rate at $400 \mathrm{~mA} \cdot \mathrm{g}^{-1}$. Measurements carried out at room temperature. EC, ethylene carbonate; DME, dimethoxyethane.

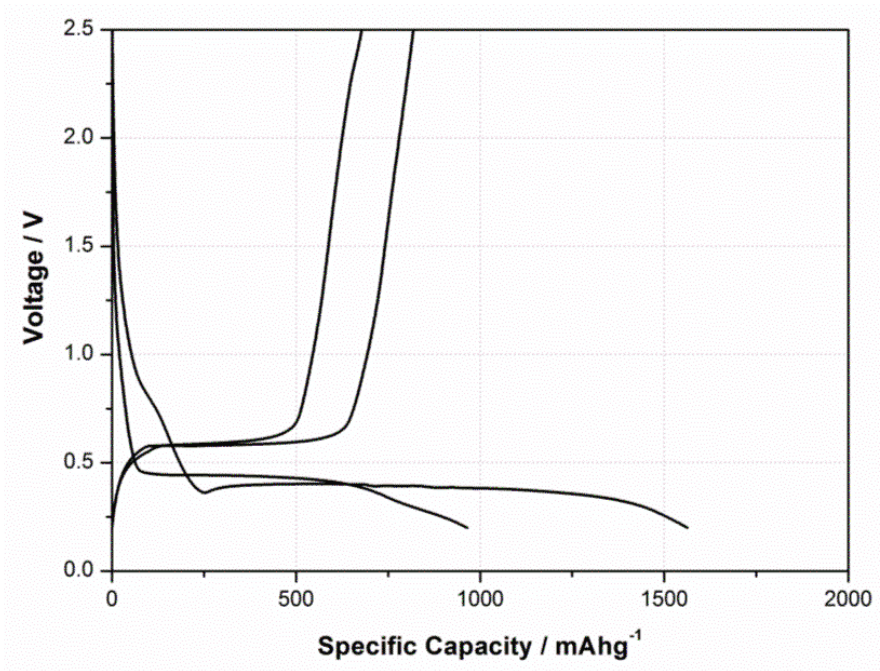

Figure 9. Galvanostatic cycling in lithium cells of $\mathrm{MgH}_{2}$ B15D5 electrodes in the ionic liquid-based electrolyte. Galvanic chain: Li/ LP30:N-n-butyl-N-methylpyrrolidinium hexafluorophosphate $\left(\left[\mathrm{Py}_{14}\right] \mathrm{PF}_{6}\right)$ 7:3/(AM 50\% carbon 30\% binder 20\%); $\mathrm{AM}=$ metallic hydride. Current rate $400 \mathrm{~mA} \cdot \mathrm{g}^{-1}$. Measurements carried out at room temperature. 
In liquid-based electrolytes (see Figure 8), we observed either an effect of the salt and of the solvents on the electrochemical response. In particular, the use of ether-based solvents improves the starting capacity, but does not improve the cell efficiency or cycling ability, whereas the use of the triflate anion in carbonate-based electrolyte instead of hexafluorophosphate causes a significant increase of cell efficiency, thus leading to a residual reversible capacity of $200 \mathrm{mAh} \cdot \mathrm{g}^{-1}$ after $10 \mathrm{cycles}$.

Ionic liquids have attracted much attention as electrolyte systems thanks to their high ionic conductivity, low toxicity, as well as their high thermal, chemical and electrochemical stability. By substituting 30\% of LP30 with [Py14]PF6, improvements in the charge efficiency of $\mathrm{MgH}_{2}$ were obtained (see Figure 9).

Analogously, the use of a PEO-based electrolyte apparently improves the electrode electrochemical response, thus boosting the reversible capacity in the first cycle to $933 \mathrm{mAh} \cdot \mathrm{g}^{-1}$ and the cycle life.

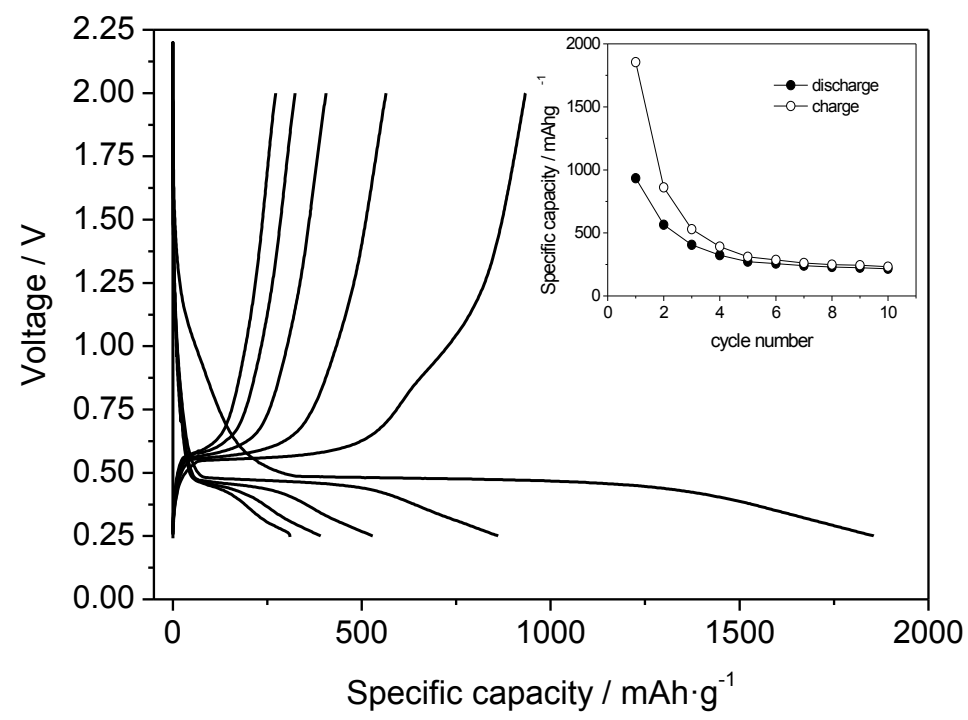

Figure 10. Galvanostatic cycling in lithium cells of $\mathrm{MgH}_{2} \_\mathrm{B} 15 \mathrm{D} 5$ electrodes in the PEO-based electrolyte. Galvanic chain: Li/PEO LiTf/(AM 50\% carbon 30\% binder 20\%); AM = metallic hydride. Current rate $100 \mathrm{~mA} \cdot \mathrm{g}^{-1}$. Measurements carried out at $110^{\circ} \mathrm{C}$.

In summary, a remarkable chance of the electrochemical responses has been observed in magnesium hydride-based electrodes by altering the electrolyte composition. Our evidence, although very limited, may suggest that the electrode/electrolyte interface is very far from being fully stable. Obviously, this analysis is only a first attempt, and much extended efforts must be accomplished in order to clarify the fundamental chemistry of the interfaces and optimize the electrochemical response of these complex electrode systems. However, this is beyond the scope of our project and of this general review.

\subsection{Li-Ion-Hydride Proof of Concept}

As the ultimate goal, the final grand target of this project has been to prove for the first time in the literature the concept of a lithium ion-hydride cell, i.e., a complete Li-ion cell where a hydride-conversion reaction (HCR) anode was coupled with a lithium insertion cathode material. A lab-scale prototype has been assembled using $\mathrm{MgH}_{2}$ B $15 \mathrm{D} 5$ as the negative electrode, commercial $\mathrm{LiFePO}_{4}$ (Custom Cell) as the positive electrode and LP30 as the electrolyte. The Li-ion cell has been assembled using a 2032 coin cell with a total capacity of $\approx 2 \mathrm{mAh}$. The mass ratio between the negative and positive electrodes has been optimized to $\mathrm{N} / \mathrm{P}=1: 11$, thus resulting in a balanced Li-ion configuration. An electrolyte volume of $25 \mu \mathrm{L} \cdot \mathrm{cm}^{-2}$ has been used. The cell has been cycled with a current rate of $0.11 \mathrm{~mA} \cdot \mathrm{cm}^{-2}$ in the voltage range $3.6-0.5 \mathrm{~V}$ with a capacity limitation of 
$2000 \mathrm{mAh} \cdot \mathrm{g}^{-1}$ with respect to the negative electrode mass. The voltage profile and the capacities upon cycling are shown in the Figure 11.

The lithium ion cell suffers from the capacity fading intrinsic to $\mathrm{MgH}_{2}$ cycling. Nevertheless, the cell shows a very interesting voltage profile, with a flat charge process at $3 \mathrm{~V}$, and discharge at $2.8 \mathrm{~V}$. High average voltage means high energy, and low voltage hysteresis grants high energy efficiency. With such features, we strongly believe that the proposed lithium ion-hydride cell deserves much attention and will focus further the scientific community onto the optimization of hydrides for electrochemical energy storage.

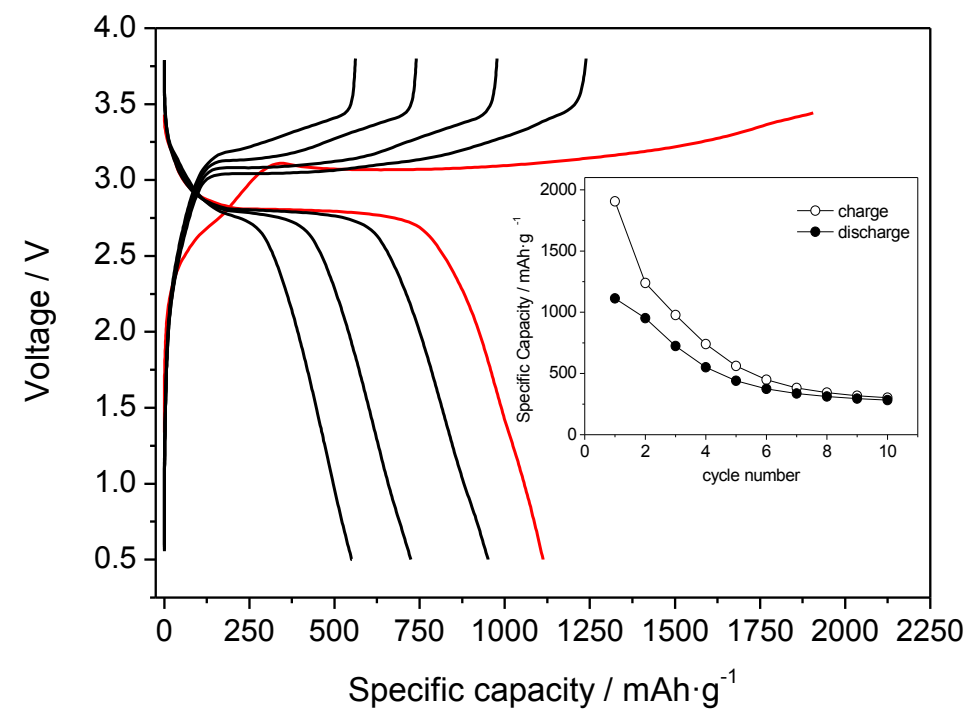

Figure 11. Galvanostatic cycling of a MgH2_B15D5/LP30/LiFePO 4 lithium ion cell. Current rate 0.11 $\mathrm{mA} \cdot \mathrm{cm}^{-2}$. Capacity values are normalized to the $\mathrm{MgH}_{2}$ mass.

\section{Conclusions}

In this review, we illustrated the most relevant results achieved in the frame of the Italian National Research Project Futuro in Ricerca di base FIRB-2010 "Hydrides as high capacity anodes in lithium cells" and possible future perspective of research for hydrides in non-aqueous lithium-based electrochemical energy storage devices.

Seventeen different candidate hydrides have been selected and grouped as follows: (i) simple metal hydrides, i.e., $\mathrm{MgH}_{2}, \mathrm{TiH}_{2}, \mathrm{NaH}, \mathrm{CaH}_{2}$; (ii) borohydrides, i.e., $\mathrm{LiBH}_{4}, \mathrm{NaBH}_{4}, \mathrm{KBH}_{4}, \mathrm{Ca}\left(\mathrm{BH}_{4}\right)_{2}$ and $\mathrm{Mg}\left(\mathrm{BH}_{4}\right)_{2}$; (iii) alanates, i.e., $\mathrm{LiAlH}_{4}, \mathrm{Li}_{3} \mathrm{AlH}_{6}, \mathrm{NaAlH}_{4}, \mathrm{Na}_{3} \mathrm{AlH}_{6}$ and $\mathrm{LiNa}_{2} \mathrm{AlH}_{6}$; (iv) other complex hydrides, i.e., $\mathrm{Mg}_{2} \mathrm{NiH}_{4}$ and $\mathrm{Mg}_{2} \mathrm{FeH}_{6}$. The electrochemical activity of all of these hydrides has been investigated and its reversibility demonstrated for $\mathrm{MgH}_{2}, \mathrm{TiH}_{2}, \mathrm{NaH}$ and the alanate-family.

Generally speaking, we carried out a comprehensive experimental and theoretical study in order to explore the basics of the HCR process. Parallel experimental and computational activities have been carried on to investigate the thermodynamic, mechanistic and kinetic aspects of the reactions.

We also investigated the effect of ball milling and the synthetic procedures on the electrochemical activity, and we preliminarily explored the role of the electrolyte and the stability of the electrolyte/electrode interface.

As a final point of this project, we demonstrated the concept of a full Li-ion hydride battery by coupling a $\mathrm{MgH}_{2}$-based negative electrode with an LFP positive electrode and a commercial liquid electrolyte in a 2-mAh coin cell demonstrator. In conclusion, our wide investigation of the HCR processes in Li-cells in the frame of the FIRB project suggests that at this point, two big challenges need to be solved: (1) the poor cycling ability and (2) the poor kinetics. In particular, concerning this last point, great efforts are required to develop a more clear description of the fundaments 
of the hydride conversion reaction kinetics. In fact, the present knowledge is poor and limited to few materials. Concerning the cycling performances in the cell, the most recent literature and our experimental evidence suggest that the adoption and optimization of more complex and tailored synthetic procedures (like impregnations of host matrixes) are apparently the most promising key strategies to disclose remarkable improvements.

Acknowledgments: The authors would like to thank the Italian MIUR for the financial support through the FIRB 2010 Futuro in Ricerca project "Idruri quali anodi ad alta capacitá per batterie Li-ione". All of the authors would like to thank the external collaborators that where involved in this FIRB project, namely Steve Greenbaum, Marie-Liesse Doublet, Phill Stallworth, Giovanna Maresca and Lisa Cirrincione.

Author Contributions: Sergio Brutti, Stefania Panero, Annalisa Paolone and Priscilla Reale designed and fully managed the project for all of the studied chemical systems. Daniele Meggiolaro was fully responsible of all of the computational studies. Francesco M. Vitucci, Jessica Manzi, David Munaò, Sara Gatto, Laura Silvestri and Luca Farina performed the experiments and analyzed the data. Sergio Brutti and Priscilla Reale wrote the paper.

Conflicts of Interest: The authors declare no conflict of interest. The founding sponsors had no role in the design of the study; in the collection, analyses or interpretation of data; in the writing of the manuscript; nor in the decision to publish the results.

\section{References}

1. Wagner, F.T.; Lakshmanan, B.; Mathias, M.F. Electrochemistry and the future of the automobile. J. Phys. Chem. Lett. 2010, 1, 2204-2219. [CrossRef]

2. Tarascon, J.-M.; Armand, M. Issues and challenges facing rechargeable lithium batteries. Nature 2001, 414, 359-367. [CrossRef] [PubMed]

3. Kim, M.G.; Cho, J. Reversible and high-capacity nanostructured electrode materials for Li-ion batteries. Adv. Funct. Mater. 2009, 19, 1497-1514. [CrossRef]

4. Farrington, M.D. Safety of lithium batteries in transportation. J. Power Sources 2001, 96, 260-265. [CrossRef]

5. Gnanaraj, J.S.; Zinigrad, E.; Asraf, L.; Gottlieb, H.E.; Sprecher, M.; Aurbach, D.; Schmidt, M. The use of accelerating rate calorimetry (ARC) for the study of the thermal reactions of Li-ion battery electrolyte solutions. J. Power Sources 2003, 119, 794-798. [CrossRef]

6. Kitoh, K.; Nemoto, H. 100 Wh large size Li-ion batteries and safety tests. J. Power Sources 1999, 81, 887-890. [CrossRef]

7. Ozawa, K. Lithium Ion Rechargeable Batteries; Wiley-VCH: Weinheim, Germany, 2009.

8. Goals for Advanced Batteries for EVs. Available online: http://www.uscar.org/guest/publications.php (accessed on 25 January 2017).

9. Bruce, P.G.; Scrosati, B.; Tarascon, J.-M. Nanomaterials for rechargeable lithium batteries. Angew. Chem. Int. Ed. 2008, 47, 2930-2946. [CrossRef] [PubMed]

10. Li, H.; Wang, Z.; Chen, L.; Huang, X. Research on advanced materials for Li-ion batteries. Adv. Mater. 2009, 21, 4593-4607. [CrossRef]

11. Tarascon, J.-M.; Poizot, P.; Laruelle, S.; Grugeon, S.; Dupont, L. Nano-sized transition-metal oxides as negative-electrode materials forlithium-ion batteries. Nature 2000, 407, 496-499. [CrossRef] [PubMed]

12. Cabana, J.; Monconduit, L.; Larcher, D.; Palacín, M.R. Beyond intercalation-based Li-ion batteries: The state of the art and challenges of electrode materials reacting through conversion reactions. Adv. Mater. 2010, 22, 170-192. [CrossRef] [PubMed]

13. Oumellal, Y.; Rougier, A.; Nazri, G.A.; Tarascon, J.-M.; Aymard, L. Metal hydrides for lithium-ion batteries. Nat. Mater. 2008, 7, 916-921. [CrossRef]

14. Oumellal, Y.; Rougier, A.; Tarascon, J.M.; Aymard, L. 2LiH + M (M = Mg, Ti): New concept of negative electrode for rechargeable lithium-ion batteries. J. Power Sources 2009, 192, 698-702. [CrossRef]

15. Zaidi, W.; Oumellal, Y.; Bonnet, J.P.; Zhang, J.; Cuevas, F.; Latroche, M.; Bobet, J.L.; Aymard, L. Carboxymethylcellulose and carboxymethylcellulose-formate as binders in $\mathrm{MgH}_{2}$-carbon composites negative electrode for lithium-ion batteries. J. Power Sources 2011, 196, 2854-2857. [CrossRef]

16. Oumellal, Y.; Zaïdi, W.; Bonnet, J.P.; Cuevas, F.; Latroche, M.; Zhang, J.; Bobet, J.L.; Rougier, A.; Aymard, L. Reactivity of $\mathrm{TiH}_{2}$ hydride with lithium ion: Evidence for a new conversion mechanism. Int. J. Hydrogen Energy 2012, 37, 7831-7835. [CrossRef] 
17. Brutti, S.; Mulas, G.; Piciollo, E.; Panero, S.; Reale, P. Magnesium hydride as a high capacity negative electrode for lithium ion batteries. J. Mater. Chem. 2012, 22, 14531-14537. [CrossRef]

18. Hirscher, H. Handobook of Hydrogen Storage; Wiley-VCH: Weinheim, Germany, 2010.

19. Fichtner, M. Conversion materials for hydrogen storage and electrochemical applications-Concepts and similarities. J. Alloys Compd. 2011, 509, S529-S534. [CrossRef]

20. IEA/DOE/SNL Hydride Databases. Available online: http://hydpark.ca.sandia.gov/DBFrame.html (accessed on 25 January 2017).

21. Varin, R.; Czujko, T.; Wronski, Z. Nanomaterials for Solid State H2 Storage; Springer: Cleveland, OH, USA, 2008.

22. Silvestri, L.; Farina, L.; Meggiolaro, D.; Panero, S.; Padella, F.; Brutti, S.; Reale, P. Reactivity of sodium alanates in lithium batteries. J. Phys. Chem. 2015, 119, 28766-28775. [CrossRef]

23. Meggiolaro, D.; Farina, L.; Silvestri, L.; Panero, S.; Brutti, S.; Reale, P. Lightweight borohydrides electro-activity in lithium cells. Energies 2016, 9, 238. [CrossRef]

24. Meggiolaro, D.; Gigli, G.; Paolone, A.; Vitucci, F.; Brutti, S. Incorporation of lithium by $\mathrm{MgH}_{2}$ : An ab initio study. J. Phys. Chem. 2013, 117, 22467-22477. [CrossRef]

25. Farina, L.; Munao, D.; Silvestri, L.; Panero, S.; Meggiolaro, D.; Brutti, S.; La Barbera, A.; Reale, P. Electrochemical activity of lightweight borohydrides in lithium cells. In Proceedings of the 2015 IEEE 15th International Conference on Environment and Electrical Engineering, EEEIC 2015, Rome, Italy, 10-13 June 2015; pp. 1827-1832.

26. Silvestri, L.; Forgia, S.; Farina, L.; Meggiolaro, D.; Panero, S.; LaBarbera, A.; Brutti, S.; Reale, P. Lithium alanates as negative electrodes in lithium-ion batteries. Chem. Electro. Chem. 2015, 2, 877-886. [CrossRef]

27. Riechel, T.L.; Wilkes, J.S. Reversible plating and stripping of sodium at inert electrodes in room temperature chloroaluminate molten salts. J. Electrochem. Soc. 1992, 139, 977. [CrossRef]

28. Vitucci, F.M.; Paolone, A.; Brutti, S.; Munaò, D.; Silvestri, L.; Panero, S.; Reale, P. $\mathrm{H}_{2}$ thermal desorption and hydride conversion reactions in Li cells of $\mathrm{TiH}_{2} / \mathrm{C}$ amorphous nanocomposites. J. Alloys Compd. 2015, 645, S46-S50. [CrossRef]

29. Farina, L.; Brutti, S.; Trequattrini, F.; Palumbo, O.; Gatto, S.; Reale, P.; Silvestri, L.; Panero, S.; Paolone, A. An extensive study of the $\mathrm{Mg}-\mathrm{Fe}-\mathrm{H}$ material obtained by reactive ball milling of $\mathrm{MgH}_{2}$ and Fe in a molar ration 3:1. Int. J. Hydrogen Energy 2017, submitted.

30. Doeff, M.M.; Chen, G.; Cabana, J.; Richardson, T.J.; Mehta, A.; Shirpour, M.; Duncan, H.; Kim, C.; Kam, K.C.; Conry, T. Characterization of electrode materials for lithium ion and sodium ion batteries using synchrotron radiation techniques. J. Vis. Exp. 2013, 11, e50594. [CrossRef] [PubMed]

31. Harks, P.P.R.M.L.; Mulder, F.M.; Notten, P.H. L. In situ methods for Li-ion battery research: A review of recent developments. J. Power Sources 2015, 288, 92-105. [CrossRef]

32. Wimmer, E.; Christensen, M.; Eyert, V.; Wolf, W.; Reith, D.; Rozanska, X.; Freeman, C.; Saxe, P. Computational materials engineering: Recent applications of VASP in the MedeA ${ }^{\circledR}$ software environment. J. Korean Ceram. Soc. 2016, 53, 263-272. [CrossRef]

33. Ben Yahia, M.; Lemoigno, F.; Rousse, G.; Boucher, F.; Tarascon, J.-M.; Doublet, M.-L. Origin of the $3.6 \mathrm{~V}$ to $3.9 \mathrm{~V}$ voltage increase in the $\mathrm{LiFeSO}_{4} \mathrm{~F}$ cathodes for Li-ion batteries. Energy Environ. Sci. 2012, 5, 9584. [CrossRef]

34. Arrouvel, C.; Parker, S.C.; Islam, M.S. Lithium insertion and transport in the $\mathrm{TiO}_{2}-\mathrm{B}$ anode material: A computational study. Chem. Mater. 2009, 21, 4778-4783. [CrossRef]

35. Hautier, G.; Jain, A.; Ong, S.P.; Kang, B.; Moore, C.; Doe, R.; Ceder, G. Phosphates as lithium-ion battery cathodes: An evaluation based on high-throughput ab initio calculations. Chem. Mater. 2011, 23, 3495-3508. [CrossRef]

36. Jónsson, E.; Johansson, P.; Xu, K. Electrochemical oxidation stability of anions for modern battery electrolytes: A CBS and DFT study. Phys. Chem. Chem. Phys. 2015, 17, 3697-3703. [CrossRef] [PubMed]

37. Urban, A.; Matts, I.; Abdellahi, A.; Ceder, G. Computational design and preparation of cation-disordered oxides for high-energy-density li-ion batteries. Adv. Energy Mater. 2016, 6, 1600488. [CrossRef]

38. Meggiolaro, D.; Gigli, G.; Paolone, A.; Reale, P.; Doublet, M.L.; Brutti, S. Origin of the voltage hysteresis of $\mathrm{MgH}_{2}$ electrodes in lithium batteries. J. Phys. Chem. 2015, 119, 17044-17052. 
39. Cirrincione, L.; Silvestri, L.; Mallia, C.; Stallworth, P.E.; Greenbaum, S.; Brutti, S.; Panero, S.; Reale, P. Investigation of the effects of mechanochemical treatment on $\mathrm{NaAlH}_{4}$ based anode materials for $\mathrm{Li}$-ion batteries. J. Electrochem. Soc. 2016, 163, A2628-A2635. [CrossRef]

40. Adelhelm, P.; de Jongh, P. The impact of carbon materials on the hydrogen storage propertie of lightmetal hydrides. J. Mater. Chem. 2011, 21, 2417. [CrossRef]

41. Gao, J.; Adelhelm, P.; Verkuijlen, H.W.; Rongeat, C.; Herrich, M.; van Bentum, P.J.M.; Gutfleisch, O.; Kentgens, A.P.M.; de Jong, K.P.; de Jongh, P.E. Confinement of $\mathrm{NaAlH}_{4}$ in nanoporous carbon: impact on $\mathrm{H}_{2}$ release, reversibility and thermodynamics. J. Phys. Chem. 2010, 114, 4675.

42. Oumellal, Y.; Zlotea, C.; Bastide, S.; Cachet-Vivier, C.; Léonel, E.; Sengmany, S.; Leroy, E.; Aymard, L.; Bonnet, J.-P.; Latroche, M. Bottom-up preparation of $\mathrm{MgH}_{2}$ nanoparticles with enhanced cycle life stability during electrochemical conversion in Li-ion batteries. Nanoscale 2014, 6, 14459-14466. [CrossRef] [PubMed]

43. Silvestri, L.; Paolone, A.; Cirrincione, L.; Stallworth, P.E.; Greenbaum, S.; Panero, S.; Brutti, S.; Reale, P. $\mathrm{NaAlH}_{4}$ nanoconfinement in mesoporous carbon for application in lithium ion batteries. J. Electrochem. Soc. 2017, submitted.

(C) 2017 by the authors. Licensee MDPI, Basel, Switzerland. This article is an open access article distributed under the terms and conditions of the Creative Commons Attribution (CC BY) license (http:/ / creativecommons.org/licenses/by/4.0/). 